Article

\title{
A Literature Review of the Impacts of Heat Stress on Human Health across Africa
}

\author{
Katlego P. Ncongwane ${ }^{1,2, *(\mathbb{D})}$, Joel O. Botai ${ }^{1,3} \mathbb{D}^{\mathbb{D}}$, Venkataraman Sivakumar ${ }^{4}$ and Christina M. Botai $^{1}(\mathbb{D}$ \\ 1 South African Weather Service, Private Bag X097, Pretoria 0001, South Africa; \\ joel.botai@weathersa.co.za (J.O.B.); christina.botai@weathersa.co.za (C.M.B.) \\ 2 School of Geography and Environmental Science, University of KwaZulu-Natal, Durban 4041, South Africa \\ 3 Department of Geography, Geoinformatics and Meteorology, University of Pretoria, Private Bag X20, Hatfield, \\ Pretoria 0028, South Africa \\ 4 School of Chemistry and Physics, University of Kwa-Zulu Natal, Durban 4041, South Africa; \\ venkataramans@ukzn.ac.za \\ * Correspondence: katlego.ncongwane@weathersa.co.za; Tel.: +27-12-367-6010
}

check for updates

Citation: Ncongwane, K.P.;

Botai, J.O.; Sivakumar, V.; Botai, C.M. A Literature Review of the Impacts of Heat Stress on Human Health across Africa. Sustainability 2021, 13, 5312. https://doi.org/10.3390/su13095312

Academic Editor: Alfonso

González González

Received: 13 April 2021

Accepted: 3 May 2021

Published: 10 May 2021

Publisher's Note: MDPI stays neutral with regard to jurisdictional claims in published maps and institutional affiliations.

Copyright: (c) 2021 by the authors. Licensee MDPI, Basel, Switzerland. This article is an open access article distributed under the terms and conditions of the Creative Commons Attribution (CC BY) license (https:/ / creativecommons.org/licenses/by/ $4.0 /)$.

\begin{abstract}
Heat stress-related illness attributed to the changing climate, particularly the more frequent extreme high temperatures, is becoming a theme of public concern, especially in the most vulnerable regions, such as the African continent. Knowledge of the existing research directions and gaps on heat stress and human health is vital for informing future strategic research foci capable of influencing policy development, planning, adaptation, and mitigation efforts. In this regard, a bibliometric analysis was conducted, with an emphasis on Africa, to assess regional research contributions to heat stress impacts on human health. The goals of the study were to review publication growth and patterns of the scientific publications and to identify key players (especially collaborating institutions and countries) and the evolution of research themes on the African continent, while paying attention to global trends and emergent hot topics and methodology of heat stress research. Using the Web of Science (WoS) and Scopus core collection databases, a structured keyword search was undertaken, which yielded 463 and 58 research publications from around the world and Africa, respectively. The retrieved scientific documents, published between 1968 and 2020, were analyzed and visualized using a bibliometric analysis technique and the VOSviewer software tool. The results indicate low statistics and slow scientific growth in publication output, with the highest peak having been reached in 2018, resulting in 13 scientific publications. While global research collaborations are successfully reflected in the literature, there is a considerable gap in understanding heat stress and related collaborations between African countries and international institutions. The review study has identified key opportunities that can benefit Africa through the expansion of the scope of heat stress and human health research on the continent. These opportunities can be achieved by closing the following research gaps: (1) vulnerability assessments within demographic classes, such as the elderly, (2) personal exposure and associated risks, (3) Urban Heat Island (UHI) evaluation for urban environments, and (4) heat adaptation research, which will enable informed and targeted preventive actions that will limit future heat health impacts. The authors opine that the pursuit of such studies will be most impactful if the current knowledge gaps are bridged through transdisciplinary research supported by local, regional, and international collaborators.
\end{abstract}

Keywords: heat stress; human health; collaboration; bibliometric study

\section{Introduction}

Climate change poses a fundamental threat to a wide range of sustainable development matters, particularly relating to health equity, food security, employment, gender equality, education, and housing, among others [1,2]. Adding to the existing threats are the immediate and long-term effects of climate change on the primary determinants of health $[3,4]$. Likewise, the ongoing socio-economic challenges have been found to worsen 
the interdisciplinary facets of extreme heat vulnerabilities stemming from the changing climate. As widely observed, the disproportional impacts of climate change on human health stem primarily from exposure to high temperatures coupled with weather extremes (i.e., heat), as well as the increased production of certain air pollutants and aeroallergens $[5,6]$. According to McMichael [5], potential health effects of climate change can be divided into direct and indirect effects, depending on whether they occur predominantly via the impacts of climate change and variability upon human biology or are mediated by climate-induced changes in other biological and biogeochemical systems. According to the Fifth Assessment Report of the Intergovernmental Panel on Climate Change (IPCC), climate change will mostly exacerbate existing health burdens by 2050, and populations currently most affected by climate-related illnesses will also be at most significant risk in the future [7]. Regions exhibiting the poorest health infrastructure will be the least able to adapt, prepare, and respond to the variety of increased health risks likely in a changing climate $[8,9]$

Heat stress, a well-established phenomenon from extreme heat exposure, is projected to intensify in the future, owing to global warming. For example, it is predicted that temperatures will increase by 1.4 to $5.8^{\circ} \mathrm{C}$ globally [10]. In Africa, the rise in temperature is projected to range between 4 and $6{ }^{\circ} \mathrm{C}$ in the subtropics and between 3 and $5{ }^{\circ} \mathrm{C}$ in the tropics by the end of the century [11]. This temperature increase is expected to exacerbate the number of extreme weather events, including heatwaves [12], which are already occurring more frequently, are more intense, and lasting longer [13]. The anticipated increase in global temperature, together with other environmental factors, such as the rise in humidity [14], will significantly increase heat health risks for the most vulnerable [4], particularly those who reside in low-income countries, such as in Africa, where coping or adaptation measures are limited ([15]. Africa, in particular, is considered to be the most vulnerable continent, with underrepresented extreme heat and heatwave exposure and corresponding heat health risks due to limited access to data [9]. Consequently, it is projected that heat-related extreme events will be more severe and more frequent in Africa than anywhere else in the world [15]. In addition, Africa's vulnerability is partially attributed to the current problems of multidimensional poverty, poor governments, and political instability, which restricts the capacity of certain countries to meet the challenges raised by climate change [16]. Being located in hot regions and showing high rates of urban population growth, African cities, in particular, will likely face significantly increased exposure to dangerous heat in the coming decades [17]. Furthermore, even under strict climate action, an increasing number of urban residents will be vulnerable to high levels of heatwaves in Africa [18].

The Urban Heat Island (UHI) phenomena and compounding factors, such as the aging population, suggest that heat health risks will be pertinent, threatening the progress towards Sustainable Development Goal 3 ("Good Health and Wellbeing") [19]. Globally, the effects of heat stress are already being felt by people of all ages. However, there are segments of the most vulnerable population-the elderly, children under the age of five, the chronically ill, the socially isolated, and high-risk occupational groups-that ought to be of concern to human health stakeholders. It is no surprise that a number of reported deaths globally, that is, approximately 70,000 and 500 in Europe in 2003 [20] and 2006 [21], respectively, 225 in North America in 2006 [22], and 55,000 in Eastern Europe and western Russia in 2010 [23], were mainly from the abovementioned vulnerable groups. Additionally, hospital admissions have been increasing due to accumulated metabolic stress on human bodies, which triggers a variety of heat stress conditions, such as heat stroke and, in some cases, exacerbating underlying medical conditions, including respiratory and cardiovascular diseases, diabetes Mellitus, and renal disease [24-26].

Heat can impact people's lives in many ways. Apart from heat health-related risk threats, high temperature-induced heat stress is increasingly becoming an impediment to socio-economic activities. Workers engaged in strenuous labor, mainly in humid and poorly ventilated environments, including those regularly exposed to hot working conditions, such as those in construction or the agricultural sector (including the fisheries and forestry 
sectors), are likely to suffer from heat stress risks $[27,28]$. Over the years, it has been proven in occupational heat exposure research that heat exposure does not only threaten the health of workers, consequentially leading to a high mortality rate (see Gun [29] and Vaidyanathan et al. [30]), but also diminishes performance and work capacity [31,32]. According to Kjelltrom et al. [33], this is a challenge for working populations in mining, agriculture, construction, quarries, and outdoor services in countries like South Africa that experience hot seasons each year. Therefore, the effects of heat stress have become most relevant, especially where there are inadequate preventive and control measures. This is particularly true in sub-Saharan Africa. Equally, in school environments, precautions should be taken in protecting schoolchildren from increased indoor and outdoor heat exposure since they are considered one of the groups susceptible to heat stress. This is because this heat stress-susceptible group is still developing physiologically and has limited capacity to cool their bodies, as has been demonstrated in several studies [34-37]. Furthermore, some of the distinctive features of urban environments (i.e., UHI), especially in cities, exposes many of the inhabitants to extreme heat, which carries health burdens beyond heat-related illnesses that are projected to increase and will affect many in the future due to rapid urbanization coupled with high population growth $[38,39]$. Undoubtedly, the anthropogenic nature of the world we live in and the projected one of the future will exacerbate the effects of heat even more and beyond the direct and indirect negative health impacts, thereby affecting key socio-economic sectors required to achieve the Sustainable Development Goals.

In response to the increasing potential threat of heat exposure and the need to reduce the risk of harm, many countries, particularly developed countries, have drafted heat action plans as per the World Health Organization (WHO) recommendation [40]. In Africa, countries such as South Africa [41] are in the process. Such plans, which are an important part of mitigation and adaptation planning [42], will ensure preparedness and timely responses by the affected communities in order to minimize heat exposure risks. However, for such plans to be developed and implemented effectively, knowledge of heat exposure risks is required. This information is limited and still emerging in low- and middle-income countries. Such inexhaustive heat stress scholarship has adverse implications on the policy developments needed to formulate adaptation measures that will influence public health decisions and the perceptions of heat health risks in Africa. Awareness of what research has been conducted and what gaps exist in the existing published literature will pave the way for strategic research and mainstreaming actions in heat health research and development. It is against this background that this present study aims to conduct a scientific mapping and analysis on heat health research studies in Africa to decipher thematic trends, patterns, and the nature of linkages (collaboration networks) inherent in the heat health scientific domain. This study, therefore, will (a) have an important scientific contribution through an exposition of the evolution of heat health research themes and methodology, and hence, help to build the heat health body of research, and (b) make a practical contribution in terms of keeping the community of practice abreast with current hot topics and the future direction of heat health research in support for policy decision-making and the development of relevant heat health interventions that are needed.

\section{Materials and Methods}

The current review study on heat stress was carried out by following a stepwise procedure often used in bibliometric analysis studies, summarized in Figure 1. The preparation of the bibliometric analysis involved firstly defining the research questions within the topic of heat stress and human health. Components of the research questions were used to decide on the geographic region covered as well as the time period for the study. A number of keywords and search topics were identified and used to retrieve published documents on heat stress and human health. In particular, the Web of Science (WoS) and Scopus databases were used to retrieve various document types on the research topic of heat stress and human health. The selected sources are core collection databases that 
provide global coverage of peer-reviewed research output, such as scientific articles, books, and conference proceedings across various disciplines.

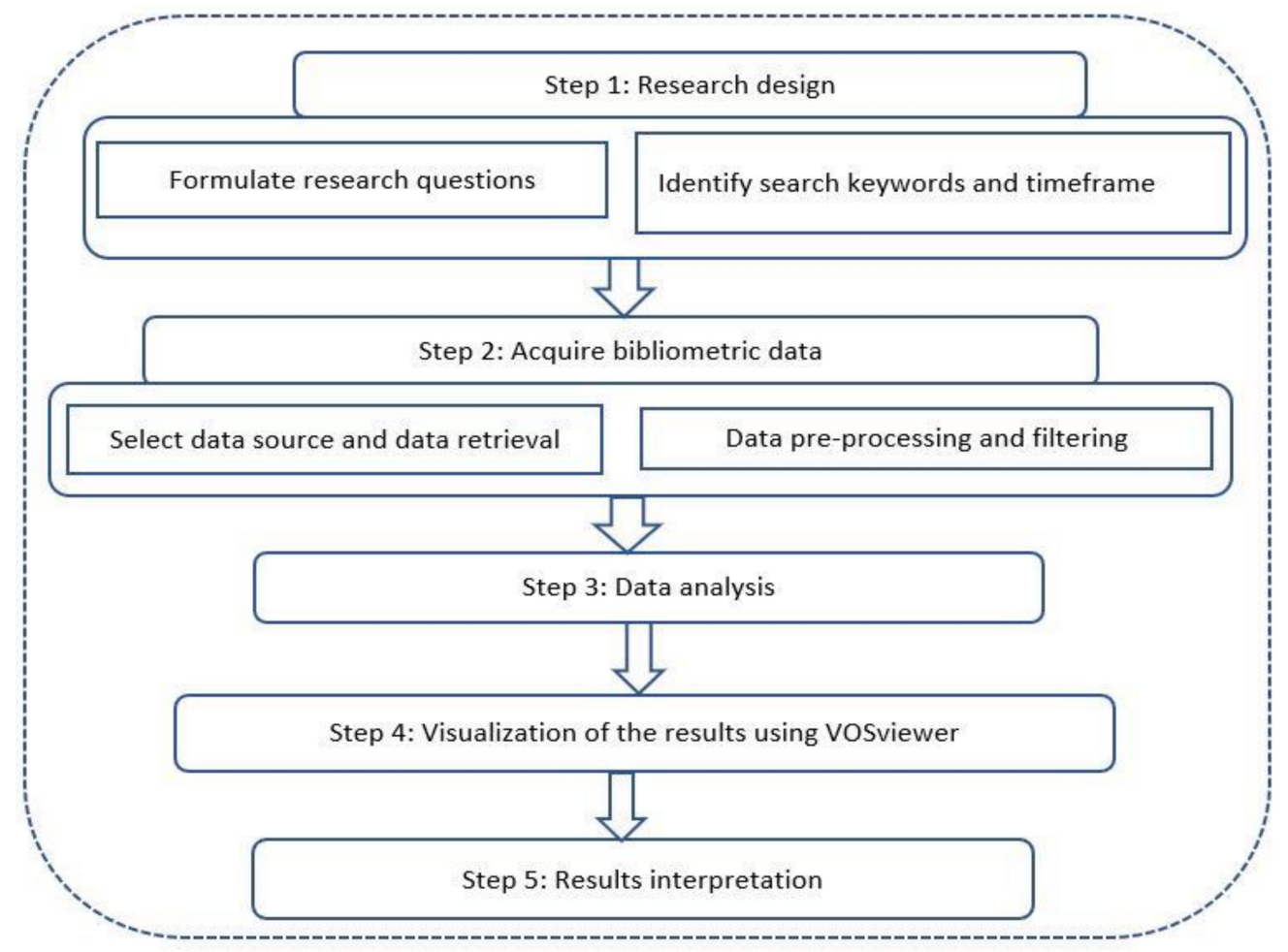

Figure 1. Workflow followed in conducting bibliometric analysis, adopted from Zupic and Cater [43].

The keywords used in the search of documents were defined in a way that limited the risk, thereby allowing the retrieval of the most published documents on the research topic of heat stress and human health. An example of research conducted in both Scopus and WoS was set by entering the search topics, as follows, on each row of the databases' web portals: "heat stress" AND "vulnerability" AND "Africa". A complete set of search topics used in the current review study is given in Table 1, with the area restricted to only Africa and an open-ended search for the global scale option. The retrieved documents contained primary information, such as authors, title, keywords, abstract text, countries, institutions, journals, and cited references, among others. After duplicated documents were removed during pre-processing, a total of 463 and 58 documents, were considered for the global and continental scales, respectively, spanning from 1968-2020 and including articles, book chapters, and conference proceedings. See Appendix A for a list of 58 documents retrieved from Africa, with a summary of respective research themes. A summary catalog of the information retrieved is given in Figure 2.

Table 1. Summary of search topics used in Scopus and Web of Science collection databases to search and retrieve heat stress-related scientific documents published in Africa.

\begin{tabular}{|c|c|c|}
\hline Search Topic (1st Row) & Areal Restriction (2nd Row) & Areal Restriction (3rd Row) \\
\hline "Heat stress" & [AND] "vulnerability" & [AND] "Africa" \\
\hline "Heat stress" & [AND] "human health" & [AND] "Africa" \\
\hline "Heat stress" & [AND] “impacts" & [AND] "Africa" \\
\hline "Heat stress" & [AND] "mortality" & [AND] "Africa" \\
\hline "Heat stress" & [AND] "hospitalization" & [AND] "Africa" \\
\hline "Heat stress" & [AND] "heat exhaustion" & [AND] "Africa" \\
\hline "Heat stress" & [AND] "dehydration" & [AND] "Africa" \\
\hline "Heat stress" & [AND] "thermal comfort" & [AND] "Africa" \\
\hline "Heat stress" & [AND] "heat stroke" & [AND] "Africa" \\
\hline
\end{tabular}




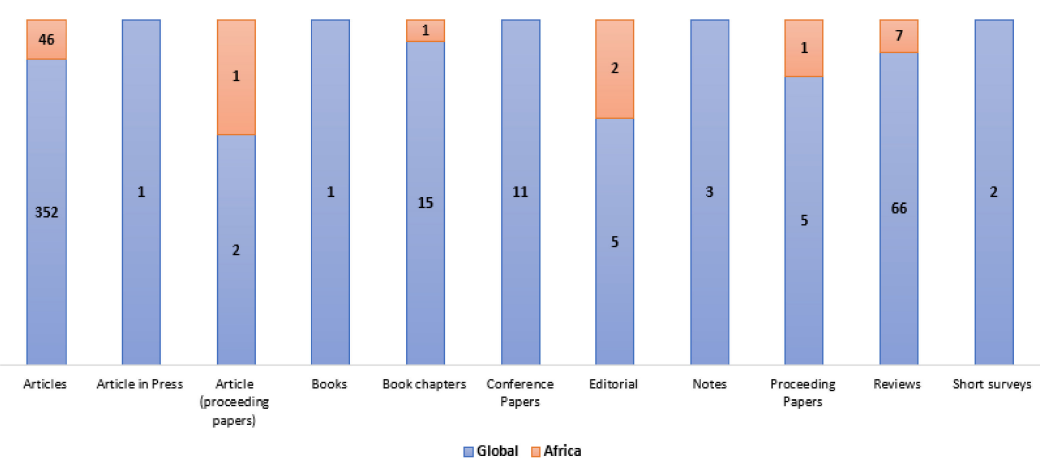

Figure 2. Catalog of the retrieved documents.

The data analysis of the retrieved documents on heat stress and human health was based on bibliometric mapping methods, and thus, we used the Bibliometrix R tool established by Aria and Cuccurullo [44]. A set of analyses covering, for instance, aspects of the annual publication growth and trends, collaborations between countries and institutions, citations and keywords frequency, and so forth, were conducted for both the global and continental data. The analyzed information was exported to the VOSviewer visualization software [45] to create network visualization maps. The interpretation of the network maps was based on the cluster size and link strength provided by VOSviewer.

\section{Results}

\subsection{Scientific Mapping of Heat Stress Research}

\subsubsection{Trends in the Scientific Publications in Heat Stress and Human Health Research}

Figure 3 illustrates the trends and patterns of the time series of scientific publications for Africa, contextualizing those published globally. Years that do not appear on the timeline had zero publication output for both the globe and the African continent. Based on the dataset, Hall [46] issued the first publication in Africa in 1968. Since then, one to three publications have been published on a sporadic basis, with an average annual percentage growth rate of about $3.1 \%$, thus indicating a marginally growing publication output trend. However, publication productivity peaked in 2018 in Africa with 13 articles, and subsequently declined by almost 50\% between 2019 and 2020. Globally, there was a gradual increase in the number of publications between 2010 and 2012, increasing from 14 to 20 publications. Noticeably, since 2013, there was a high growth trend in the number of publications, increasing from about 40 to 48 articles by the year 2020, a large proportion of which has been published in the last eight years. In 2019, the global publications reached a high of 59 articles. The global annual percentage growth is $7.7 \%$-nearly twice the annual percentage growth rate for Africa.

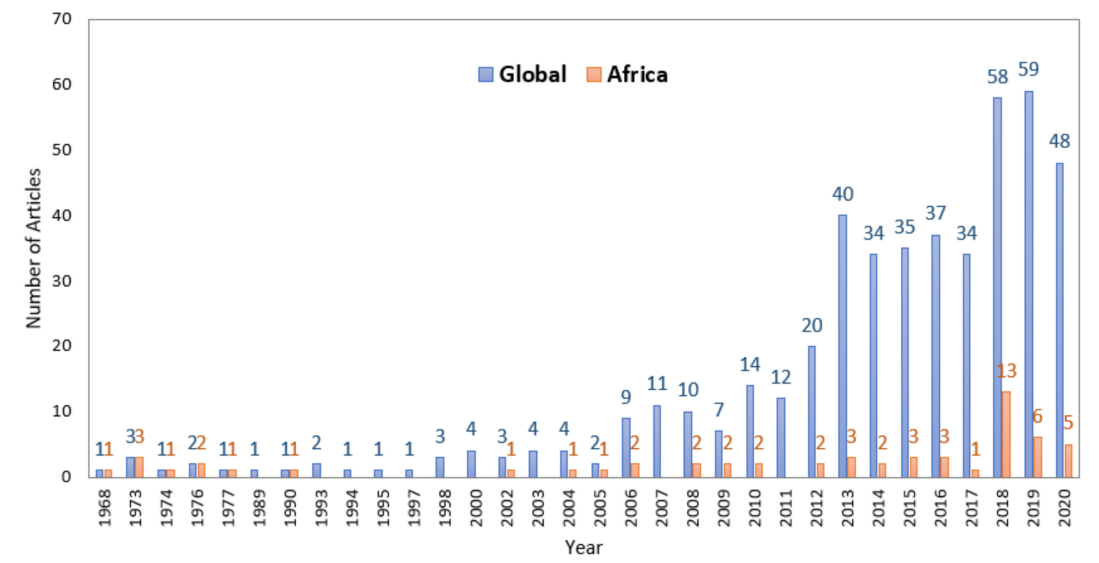

Figure 3. Annual scientific production for the globe and Africa on human heat stress research from 1968-2020. 


\subsubsection{The Most Productive Countries}

Various countries, both in Africa and globally, have contributed to the research on human heat stress. However, the heat stress scientific domain has not received equal attention in Africa as compared to most developed countries. Figure 4 illustrates the top 10 active countries globally; Table 2 illustrates the top 5 countries leading in human heat stress research in Africa. The identified leading countries are ranked based on the affiliation of the respective author's country. As depicted in Table 2, South Africa is the most productive country in Africa, significantly dominating with 8 publications, all published through Single Country Publications (SCPs), that is, all authors are from the same country and reflect intra-country collaboration. These articles have received a total of 45 citations from the literature. Germany, the United Kingdom (UK), and the United States rank second with 4 publications each, all through SCPs, with exceptions in Germany. For Germany, 3 articles were published under an SCP, whereas 1 was published under Multiple Country Publications (MCP) and has been cited the most (271 citations) in the literature. In MCP publications, authors are from various countries and represent inter-country, or worldwide, collaboration. Generally, most of the published articles in Africa resulted from SCPs, with less than $13 \%$ of the publications resulting from MCPs. From the global perspective (see Figure 4), the United States has the highest number of publications, the majority (95\%) of which are published through an SCP. Germany again takes the second lead with 34 scientific publications, followed by China, Australia, and the United Kingdom with 26, 23, and 16 combined articles, respectively.

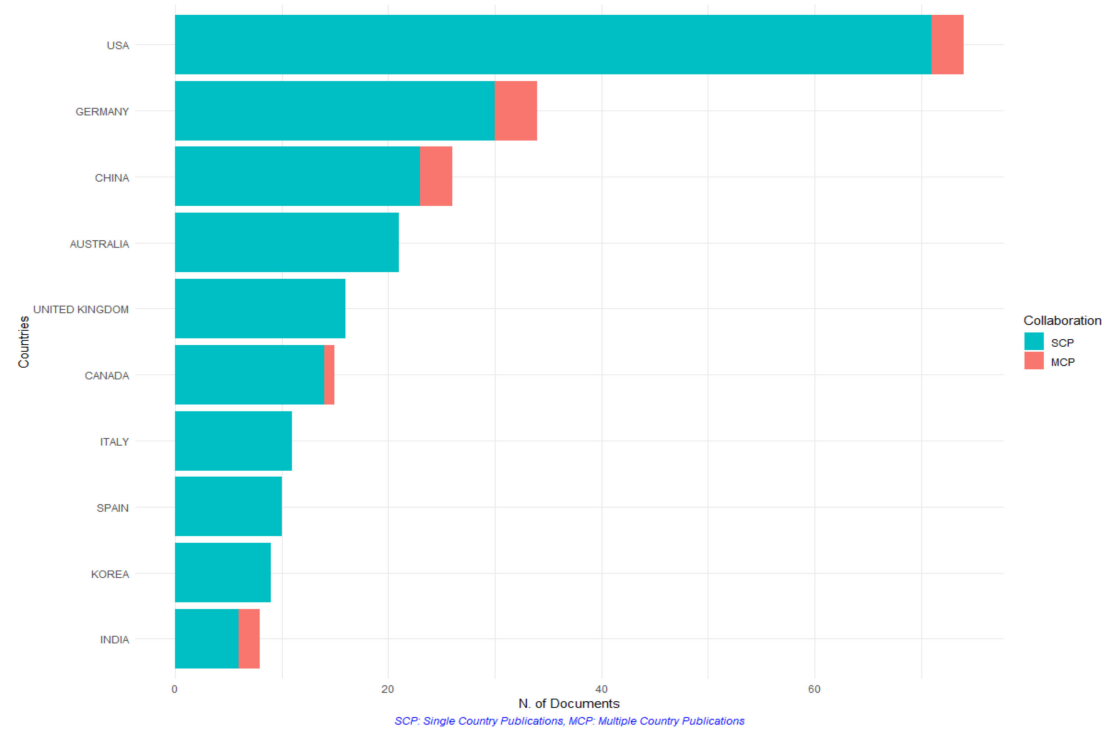

Figure 4. The top 10 most productive countries in the production of scientific publications on heat stress and human health, based on global scientific publications. The countries are ranked based on the affiliation of the first author in the article. The green color corresponds to Single Country Publications (SCPs), whereas red indicates Multiple Country Publications (MCPs).

Table 2. The top five leading countries based on the affiliation of the corresponding author. SCPSingle Country Publications, MCP-Multiple Country Publications.

\begin{tabular}{lcccc}
\hline \multicolumn{1}{c}{ Country } & Articles & SCP & MCP & Total Citations \\
\hline South Africa & 8 & 8 & 0 & 46 \\
Germany & 4 & 3 & 1 & 271 \\
United Kingdom & 4 & 4 & 0 & 31 \\
United States of & 4 & 4 & 0 & 76 \\
America & 3 & 2 & 1 & 84 \\
New Zealand & & & \\
\hline
\end{tabular}




\subsubsection{Journals with Top Manuscript as per Citations}

The 58 scientific publications retrieved and analyzed in the current review study were published in various journals. The top 10 journals that have published heat stress and human health-related research in Africa are summarized in descending order in Table 3. The ranking of the journals is based on the total citations of the published manuscripts. Consequently, approximately $17 \%$ of the articles were published in the top 10 journals given in Table 3. The published articles are scattered in the human heat stress-related field of research in Africa. The top journal publisher observed in this review is the Proceedings of the National Academy of Sciences of the USA, which resulted in 174 citations of the published manuscript, followed by the Journal of Climate, Climate Research, and Environmental Research Letters with 152, 98, and 55 total citations per manuscript, respectively. The Environmental Health Global Access Science Source and Environmental Research Letters are the lowest in the top 10 journals, with 31 and 30 citations per manuscript, respectively.

Table 3. Top 10 manuscripts per citation based on heat stress and human health research in Africa. TC-Total Citations, TCPY_-Total Citations Per Year.

\begin{tabular}{lcc}
\hline \multicolumn{1}{c}{ Journal Name } & TC & TCPY \\
\hline Proceedings of the National Academy of Sciences of the USA & 174 & 19.33 \\
\hline Journal of Climate & 152 & 11.69 \\
\hline Climate Research & 98 & 5.76 \\
\hline Environmental Research Letters & 55 & 13.75 \\
\hline Global Health Action & 48 & 4.00 \\
\hline Journal of Travel Medicine & 46 & 3.54 \\
\hline American Journal of Industrial Medicine & 40 & 2.22 \\
\hline Proceedings of the National Academy of Sciences of the USA & 38 & 4.22 \\
\hline Environmental Health Global Access Science Source & 31 & 3.44 \\
\hline Environmental Research Letters & 30 & 4.29 \\
\hline
\end{tabular}

\subsubsection{Country Collaboration Network}

In this analysis, the VOSviewer software $[45,47]$ was used to construct and visualize the bibliometric collaboration network between countries that have published scientific documents on heat stress and human health-related research, both globally and across Africa. The analysis results are presented in Figure 5 (global) and Figure 6 (Africa). The countries are assigned into various clusters, as can be seen from the VOSviewer network, with the scale of the cluster reflecting a given country's close collaboration with other countries. Most of the countries seen in the network fall in the top 10 leading countries illustrated in Figure 4. The network mapping yielded seven main clusters, as shown in Figure 5, for the global scientific analysis. The red cluster contains the most countries (5), with Brazil, France, and Greece having collaborated with 6 countries each, followed by Russia and Portugal with 5 and 2 associated links, respectively. The green cluster comes second, depicting the collaborations of 4 countries, where Canada has 4 associated links with other countries, followed by the United Kingdom [3], China [3], and Australia [2]. The remaining five clusters consist of 2 countries per group. For instance, Germany and Austria, in the blue cluster, are composed of 11 and 1 collaboration links; India and Italy (yellow) with 3 and 1 links; the Netherlands and Belgium (pink cluster) with 2 and 1 links; the United States and Japan (light blue) with 10 and 1 links, and the Czech Republic and Korea (orange) with 3 and 1 collaboration links, respectively.

Based on the results shown in Figure 6, countries in Africa offer less collaboration with domestic and international countries. As shown in Figure 6, the network depicts only the countries that have collaborated with others during the study period. The network classifies the countries into three clusters. The purple cluster shows the main country collaborations, 
with 4 countries having collaborated among themselves, as well as with Germany in the blue cluster. Collaborations between these countries suggest similar research interests within the field of heat stress and human health research. The green cluster had a strong collaboration with Australia, Sweden, and New Zealand, also suggesting common scientific priorities in heat stress and human health research subject matter.

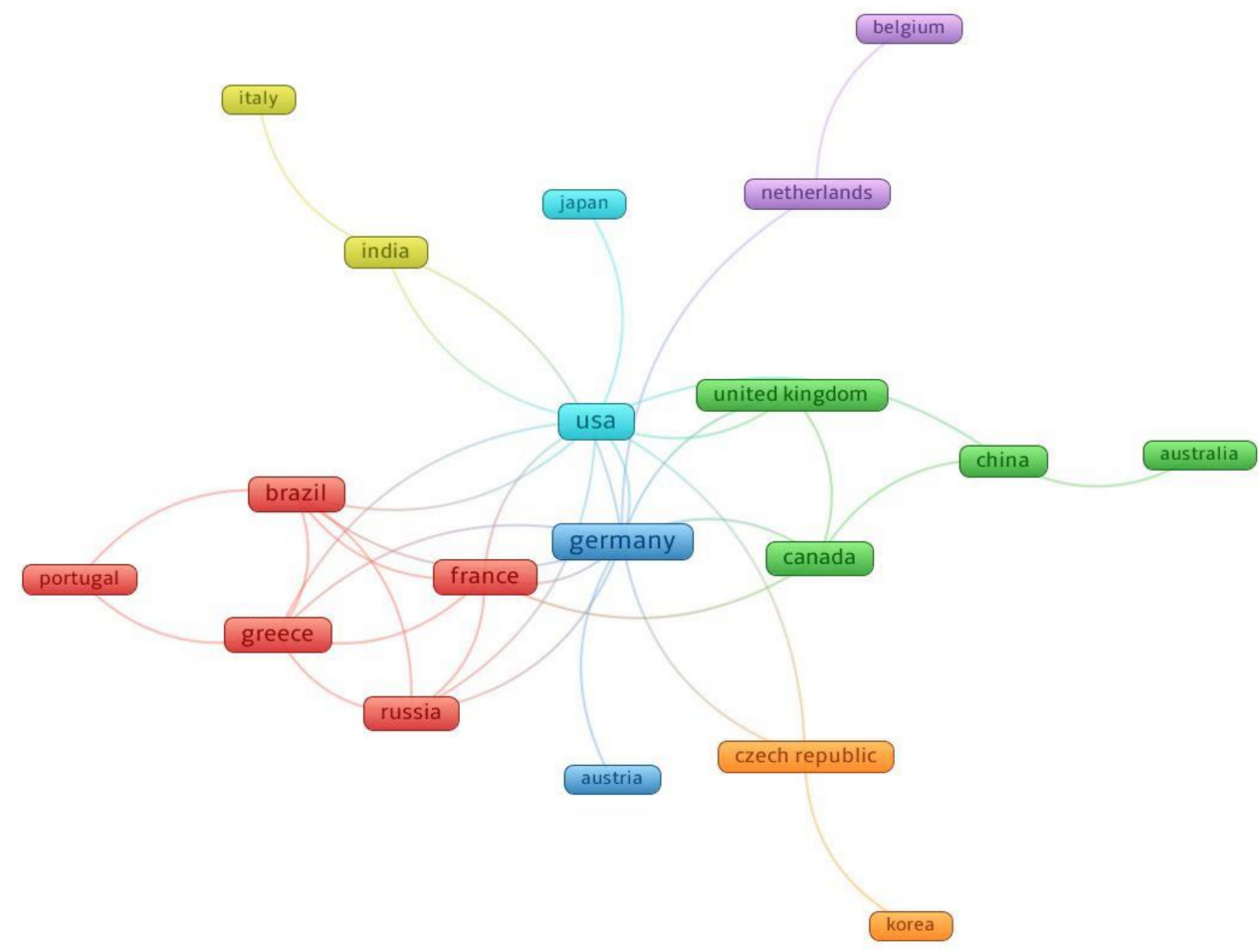

Figure 5. Countries collaboration network based on analysis of heat stress and human health published document globally.

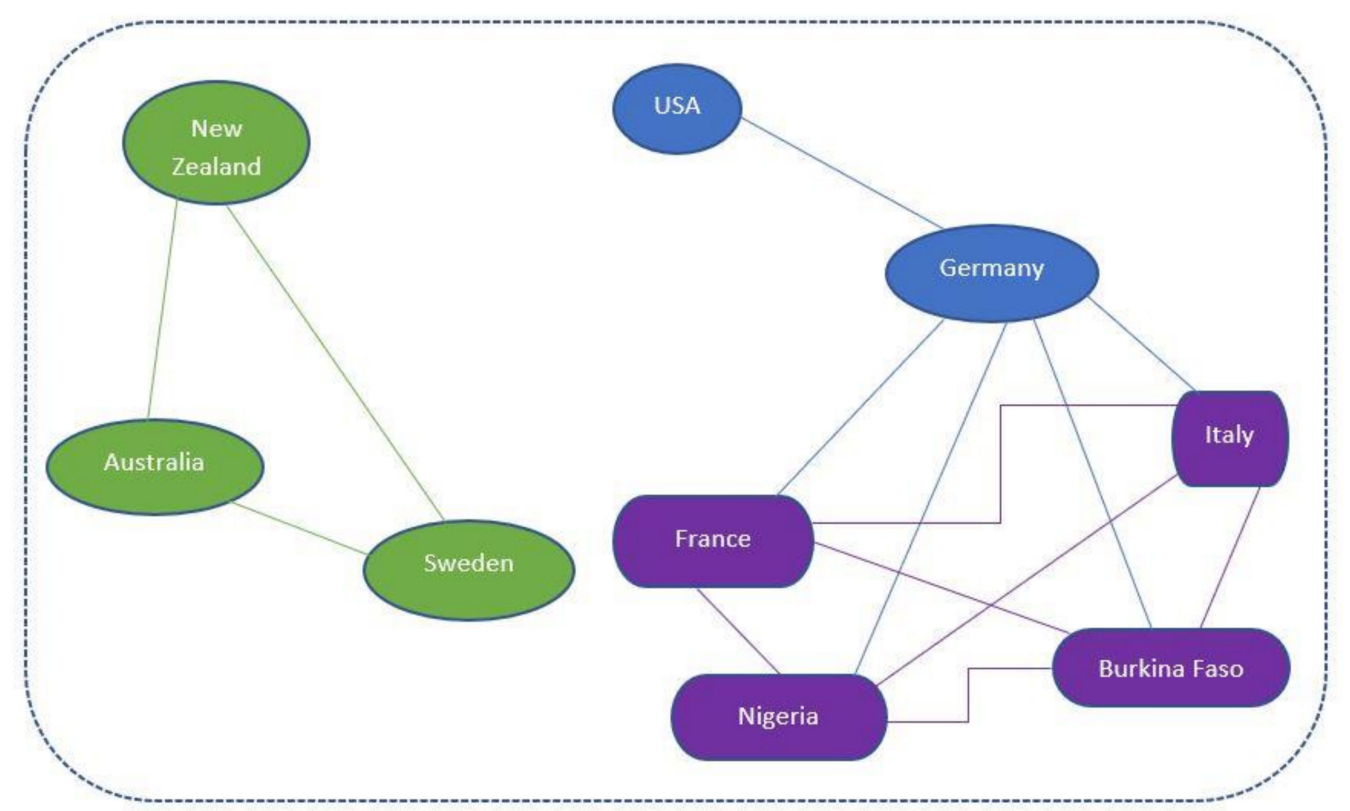

Figure 6. Country collaboration network based on the analysis of published documents on heat stress and human health in Africa. 


\subsubsection{Institution Collaboration Network}

Similar to the country collaboration mapping, the VOSviewer analysis was used to visualize the global and Africa collaboration network according to the researcher's institutions. Portrayed in Figure 7a are 5 institution collaboration clusters suggesting strong collaboration in scientific publications among global institutions. The largest and densest cluster is the red cluster, consisting mainly of university institutions in Australia, China, Japan, and the United States. Linked to these universities are two non-academic institutions, namely the National Cancer Institution (NCI), a United States federal government's principal agency for cancer research and training, as well as the Research Centre for Artificial Intelligence (Deutsches Forschungszentrum für Künstliche Intelligenz) in Germany. The blue cluster connects with the red cluster through Yale and Columbia Universities, the two dominant universities in the United States. The latter academic institutions connect to the yellow cluster through the Arizona State University and the University of Washington, both in the United States. The National Centre for Atmospheric Science in the United Kingdom and Beijing Normal University in China completes the yellow cluster collaboration. The University of Colorado in Boulder, USA, links the green cluster, which is the second dominating cluster in the institution collaboration network mapping. With the exception of Khon Kaen University in southeastern Asia and the University of Kelaniya, the green cluster is dominated by research institutions in (1) Mexico (Instituto Nacional de Cardiología Ignacio Chávez), (2) Paraguay (Centro de Hemodialisis Hospital), (3) India (Madras Medical Mission Hospital), (4) Australia (George Institute for Global Health) and lastly, (5) the Cooperative Institute for Research in Environmental Sciences (CIRES) in the United States. The relatively small cluster in the global mapping is the purple cluster that links to the red dominating cluster through the Ludwig Maximilian University of Munich in Germany.

There are 6 clusters showing institution collaboration among the African institutions, and institutions from outside Africa are shown in Figure $7 \mathrm{~b}$. Institution collaborations in Africa were dominated by institutions from the United Kingdom and Asian countries. In the red cluster are the Medical Research Institute (IMIM) and the Spanish Consortium for Research, both located in Spain. In addition, the University of Athens in Greece, Lazio Regional Health Services in Italy, l'Institut Pasteur de Tunis in Tunisia, and the Universidade de Lisboa in Portugal are linked to each other in the red cluster. Institutions from outside Africa connect with African institutions through the Federal University of Technology Owerri in Nigeria, a country located in the southeast of West Africa. The teal cluster is the smallest in comparison to other clusters in the institution network in Africa; it connects with the purple cluster through Tlhoeko Environmental Consultants in Maseru, Lesotho, and also connects with the blue cluster through the University of Chinese Academy of Sciences in Huairou District, China. In the center of the blue cluster is the Geographic Sciences and Natural Resources Research of the Chinese Academy of Sciences linked to Basel University in Switzerland, the University of Oxford in the United Kingdom, and Paris-Saclay University in France. The latter two universities are connected to the Royal Centre for Defence Medicine (RCDM), which connects with the United Kingdom-based institutions in the yellow cluster, including Birmingham Heartlands Hospital (BHH) and the Academic Department of Military Rehabilitation. The purple cluster comprises the institution in South Africa, including North-West University, the University of Pretoria, and the South African Medical Research Council (SAMRC). 


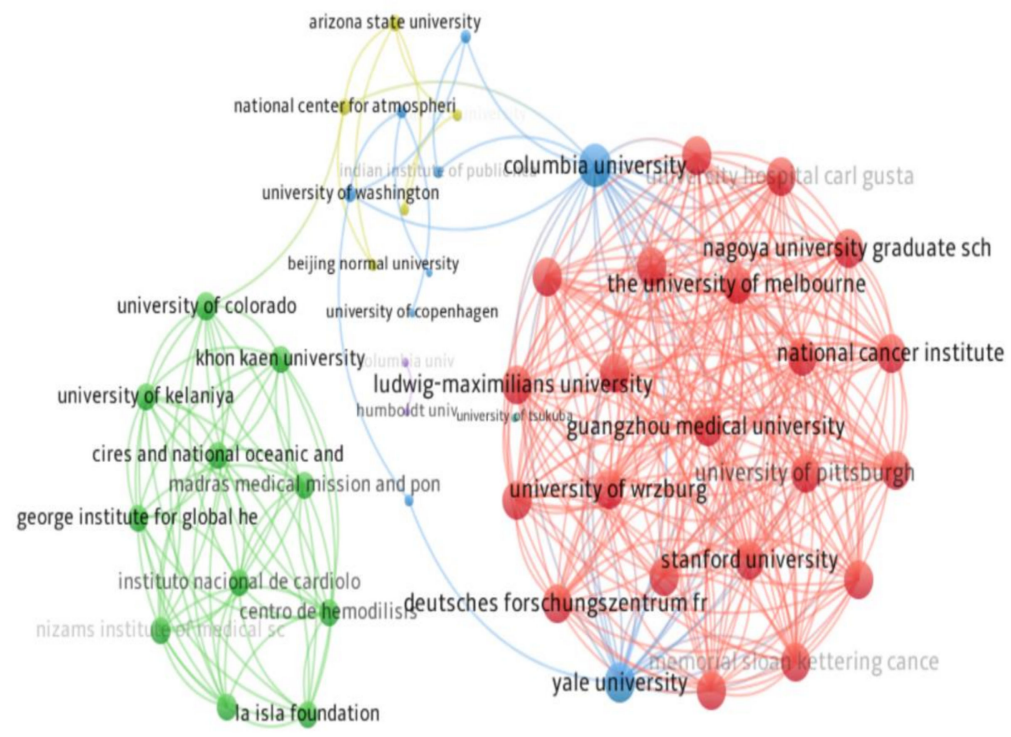

(a)

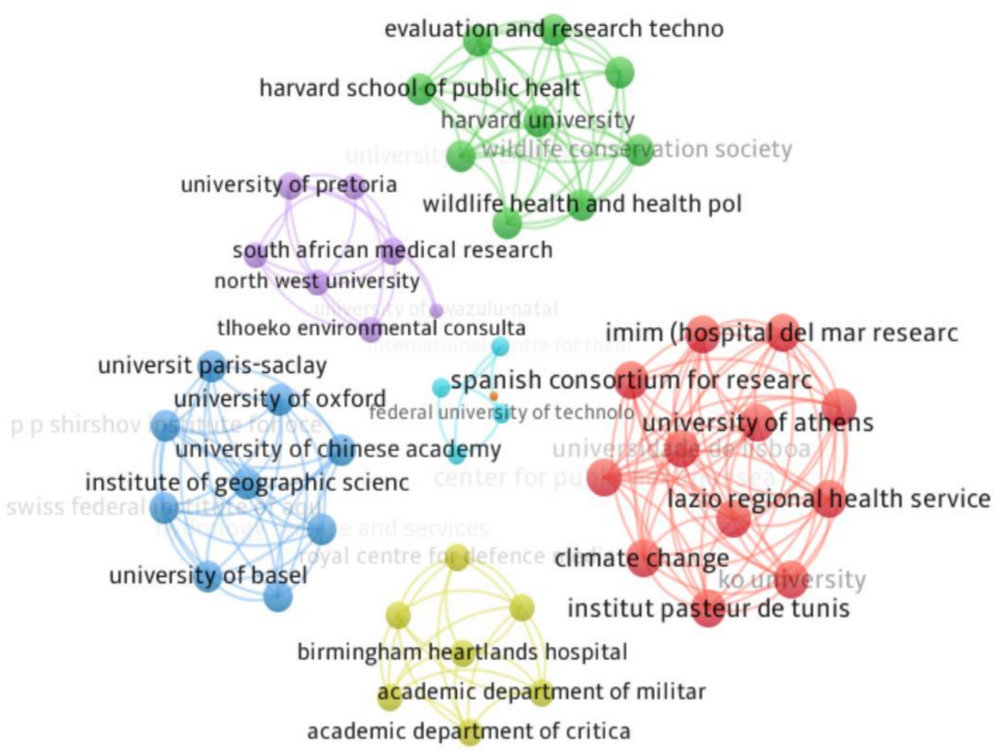

(b)

Figure 7. Institution collaboration network depicting the analysis and visualization of institutions' collaboration networks for (a) global and (b) Africa.

\subsubsection{Keywords Co-Occurrence Analysis}

The VOSviewer software was used to create a density visualization of the keywords' co-occurrences from heat stress and human health research at a global and continental (Africa) scale. The results for the global scale analysis are depicted in Figure 8. The keywords were assigned to specific clusters, where each cluster in the density visualization map is accompanied by a specific color corresponding to the density of the cluster. As noted in Figure 8 and Table 4, the keywords were assigned to five main density clusters. The keywords in the red density cluster appear more frequently, referred to in approximately 44 documents. This suggests that most researchers have paid uttermost attention to words such as "climate change", "environmental exposure", "environmental health", "extreme", "event", "health hazards", "health risks", "heatwave", "high temperature", "morbidity", and "mortality", among others, when conducting human heat stress research globally. More frequent keywords relating to a vulnerable population (see Table 4) are also observed in the green density cluster, attracting more attention to researchers, as they were referred to 
in approximately 23 scientific articles published in human heat stress-related research. The scientific community has also shown moderate interest in keywords in the blue and yellow density clusters, which include "heat shock response", "heat stress", and "oxidative stress", as well as "age factors", "demography", "risk factors", and "socio-economic factors", among others, respectively. On the contrary, the keywords in the purple density cluster appear less frequently, suggesting that researchers are paying minimal attention to aspects of heat stress with inherent impacts, such as heat injury, heat stress disorder, and changing temperatures, and their effects on humans. The differences of keyword co-occurrence results inherent in the clusters could be attributed to the geographical differences, the design (content and research questions) and the methodology of a scientific topic, or the priority research interests of institutions and countries.

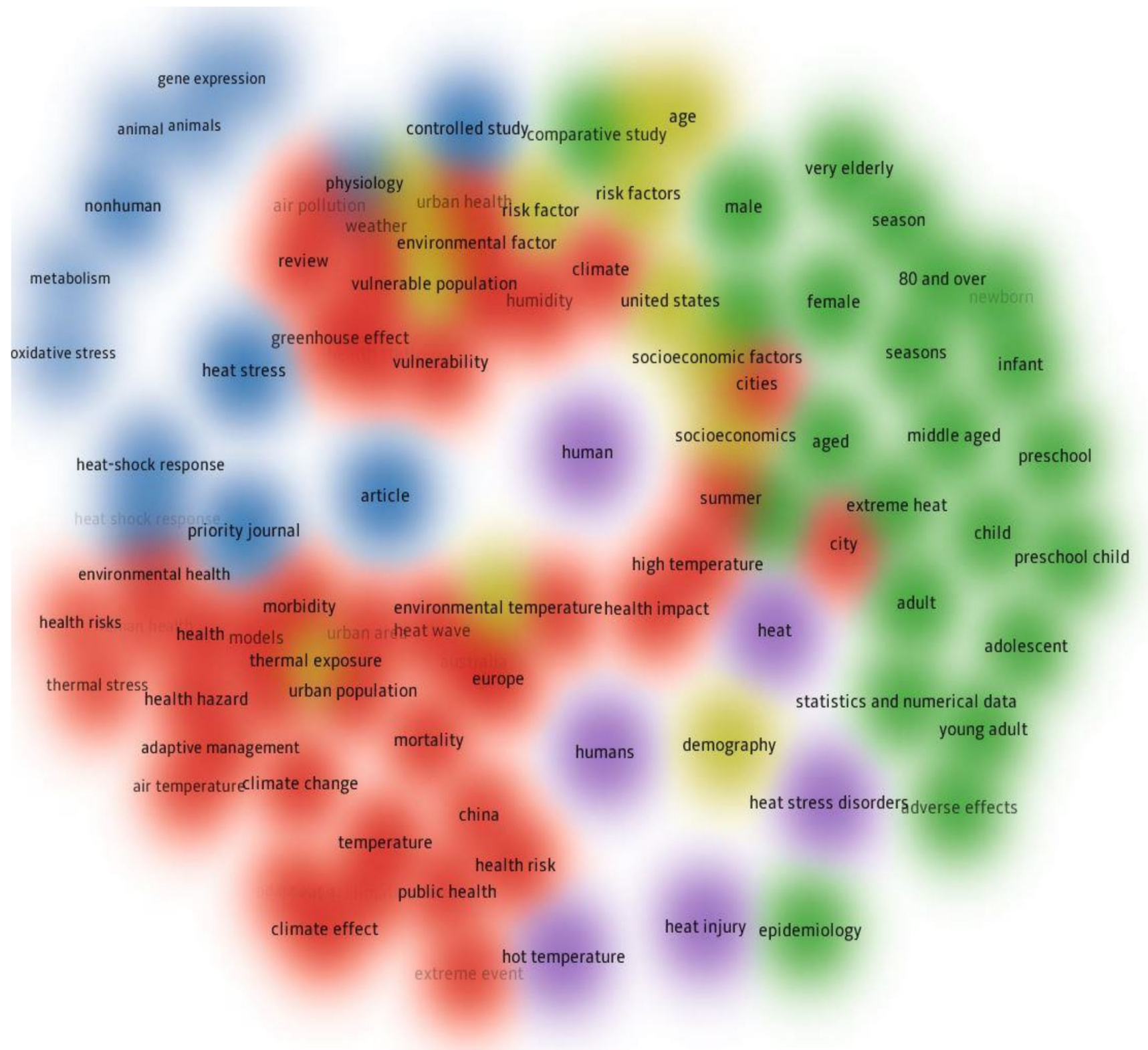

Figure 8. Keyword co-occurrences in human heat stress research derived from global scientific publications. 
Table 4. Classification of keyword co-occurrences based on heat stress and human health data collected at a global scale.

\begin{tabular}{ccl}
\hline Cluster & $\begin{array}{c}\text { No. of } \\
\text { Documents }\end{array}$ & \multicolumn{1}{c}{ Most Frequent Words } \\
\hline Red & 44 & $\begin{array}{l}\text { Adaptive management, air pollution, climate change, environmental exposure, } \\
\text { environmental health, extreme, event, health hazards, health risks, heatwave, high } \\
\text { temperature, morbidity, mortality, risk assessment, urban health, thermal stress }\end{array}$ \\
\hline Green & 23 & $\begin{array}{l}\text { Adult, } 80 \text { and over, male, female, young adult, middle-aged, newborn and preschool, } \\
\text { extreme heat, cause of death }\end{array}$ \\
\hline Blue & 14 & Heat shock response, heat stress, oxidative stress, gene expression, genetics, animals \\
\hline Yellow & 13 & $\begin{array}{l}\text { Age factors, demography, risk factors, socio-economic factors, thermal exposure, } \\
\text { vulnerable population }\end{array}$ \\
\hline Purple & 6 & Heat injury, heat stress disorder, hot temperature, humans \\
\hline
\end{tabular}

Analysis of keyword co-occurrences based on heat stress and human health research conducted in Africa resulted in 6 clusters, each identifying a particular sub-group or theme, as shown in Figure 9 and Table 5. The theme or sub-group in each keyword co-occurrencebased cluster was classified based on the words involved. In Table 5, Column 2 indicates the number of scientific articles in each cluster, whereas Column 3 depicts the associated frequency of the keywords. Consequently, the main red cluster, with 23 documents, is composed of terms that address the "health hazards" subject group, the top words being "mortality", with 58 association links, followed by "health hazard" (55), "public health" (53), "risk factor" (50), "diarrhea" (40), and "morbidity" (36). The high number of documents in the red cluster suggests that scientists have paid uttermost attention to the words in heat stress and human health research in the African continent. The vulnerability groups of heat stress are identified in the green cluster, with 13 documents paying more attention to human heat stress research in Africa. Identified vulnerability groups include "male", with 52 associated links, "adult" (51), "female" (50), "middle-aged" (46), "adolescent" (47), "child" (40), and "young adult" (37).

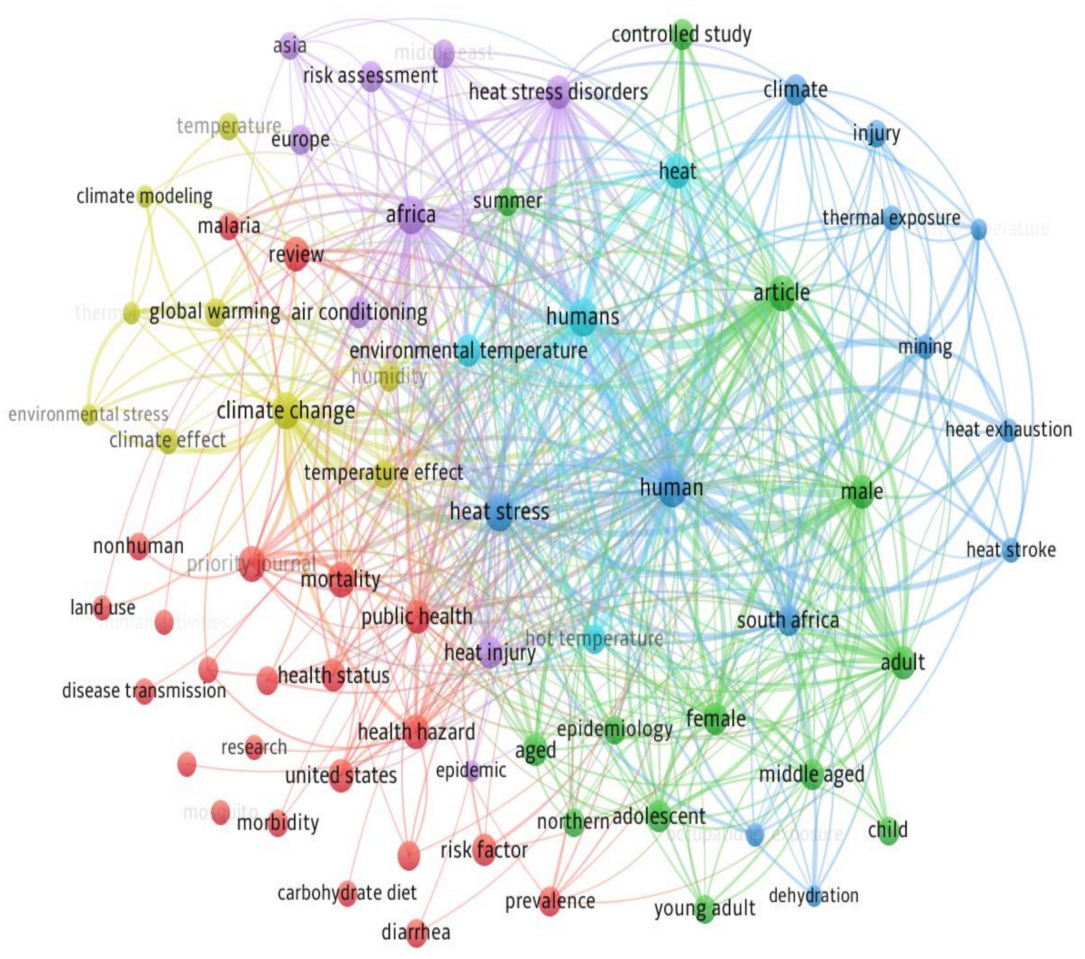

Figure 9. Keyword co-occurrences in heat stress and human health research based on the African context. 
Table 5. Classification of keyword co-occurrences by clusters based on the continental scientific data.

\begin{tabular}{|c|c|c|c|}
\hline Cluster (Sub-Field) & No. of Documents & Selected Top Words (No. of Links) & Remarks \\
\hline Red (health hazards) & 23 & $\begin{array}{l}\text { Mortality (58); health hazard (55); public } \\
\text { health (53); risk factor ( } 50) \text {; diarrhea ( } 40 \text { ) } \\
\text { morbidity ( } 36 \text { ); malaria ( } 35) \text {; disease } \\
\text { transmission (32); mosquito ( } 30)\end{array}$ & $\begin{array}{l}\text { Most researchers (i.e., } 23 \text { documents) have } \\
\text { paid utmost attention to the theme of } \\
\text { health hazard in heat stress and human } \\
\text { health research in Africa. }\end{array}$ \\
\hline Green (vulnerability groups) & 13 & $\begin{array}{l}\text { Male (52); adult (51); female (50); } \\
\text { middle-aged (46); adolescent (47); } \\
\text { child (40); young adult (37) }\end{array}$ & $\begin{array}{l}\text { The scientific community ( } 13 \text { articles) has } \\
\text { paid high attention to the most vulnerable } \\
\text { groups affected by heat stress-related } \\
\text { illness in Africa. }\end{array}$ \\
\hline Blue (impacts) & 12 & $\begin{array}{l}\text { Heat stress (67); injury (35); heatstroke } \\
\text { (29); thermal exposure (29); heat } \\
\text { exhaustion (28); dehydration ( } 22)\end{array}$ & $\begin{array}{l}\text { The scientific community has paid } \\
\text { moderate attention to the inherent impacts } \\
\text { of heat stress-related illness in Africa. }\end{array}$ \\
\hline Yellow (climate change) & 9 & $\begin{array}{l}\text { Climate change (62); global warming } \\
\text { (40); temperature effect (40); humidity } \\
\text { (38); climate effect (33); climate } \\
\text { modelling (25); thermal stress (25) }\end{array}$ & $\begin{array}{l}\text { Heat stress is attributed to climate change } \\
\text { and variability; hence, the theme draws } \\
\text { modest attention when addressing issues } \\
\text { relating to heat stress in Africa }\end{array}$ \\
\hline Purple (areas) & 9 & $\begin{array}{l}\text { Africa (66); Middle East (40); } \\
\text { Europe (42); Asia (34) }\end{array}$ & $\begin{array}{l}\text { Approximately } 9 \text { documents paid } \\
\text { attention to the identified areas in heat } \\
\text { stress and human health research, with } \\
\text { Africa leading. }\end{array}$ \\
\hline Teal (temperature variability) & 4 & $\begin{array}{l}\text { Humans (69); heat (55); environmental } \\
\text { temperature (47); hot temperature (42) }\end{array}$ & $\begin{array}{l}\text { Changes in temperature have a direct } \\
\text { impact on humans. However, the theme } \\
\text { draws minimal attention when addressing } \\
\text { aspects of heat stress in Africa }\end{array}$ \\
\hline
\end{tabular}

The blue cluster keywords cover the general impacts of heat stress, and these appear in 12 documents. The identified impacts include "heat stress" (67), "injury" (35), "heat stroke" (29), "thermal exposure" (29), "heat exhaustion" (28), and "dehydration" (22). Climate change is identified in the yellow cluster as the main subject group, covering words such as "climate change" with 62 associated links, followed by "global warming" (40), "temperature effect" (40), and "humidity" (38), among others. Approximately nine scientific articles paid attention to climate change in human heat stress research in Africa during the analyzed period. The purple cluster identified study areas considered in human heat stress research, including Africa, with the highest number of association links (62), followed by the Middle East (40), Europe (42), and Asia (34). The highest number of association links in Africa confirms the continent's vulnerability to heat stress attributed to the changing climate. The teal is the cluster that least addresses issues of the changing temperature. Only 4 documents paid attention to the sub-group in Africa, focusing on terms such as "heat" (55), "environmental temperature" (47), and "hot temperature" (42), and their impacts on humans (69).

\subsubsection{Network of Themes}

To visualize the evolution of research themes in heat stress and human health research, Cobo et al. [48]'s method was used to create two-dimensional thematic maps based on the most notable keywords and key research domains, also known as themes, shown in Figure 10. The quadrant themes consist of positive and negative values along the $\mathrm{x}$ - and $y$-axes, and they are characterized by their centrality and density rank values. The size of the spheres is proportional to the number of occurrences of keywords associated with each theme. The upper right quadrant indicates the motor themes, also referred to as the "hot topics"; the upper left quadrant displays very specialized themes; the lower right quadrant corresponds to the general transversal and basic themes; and lastly, the lower left quadrant consists of emerging or disappearing themes.

Based on the global research analysis (Figure 10), the themes "climate change", "heat stress", "extreme heat", "mortality", "extreme heatwave", "urban heat island", "climate", "adaptation", and "elderly" in the lower right quadrant are the most basic, transversal, and relevant to the heat stress and human health research field. The motor themes in 
the upper right quadrant reflect high density and strong centrality; these are "oxidative stress", "hyperthermia", "mitochondria", "vulnerability", "heat", and "public health", for the global context. The position of themes in this quadrant suggests that they are well developed and integral to current research developments in human health and heat stress subject matter. Themes in the lower left quadrant, such as "diseases", "conservation", "global warming", "heat adaptation", and "hydration", have high density but low centrality and are, therefore, of marginal relevance to the heat stress and human health subject in the global perspective. In addition, themes such as "gene expression", "stress response", "virulence", "build environment", "urban design", and "microclimate" are considered to be emerging or disappearing, with low density and centrality.

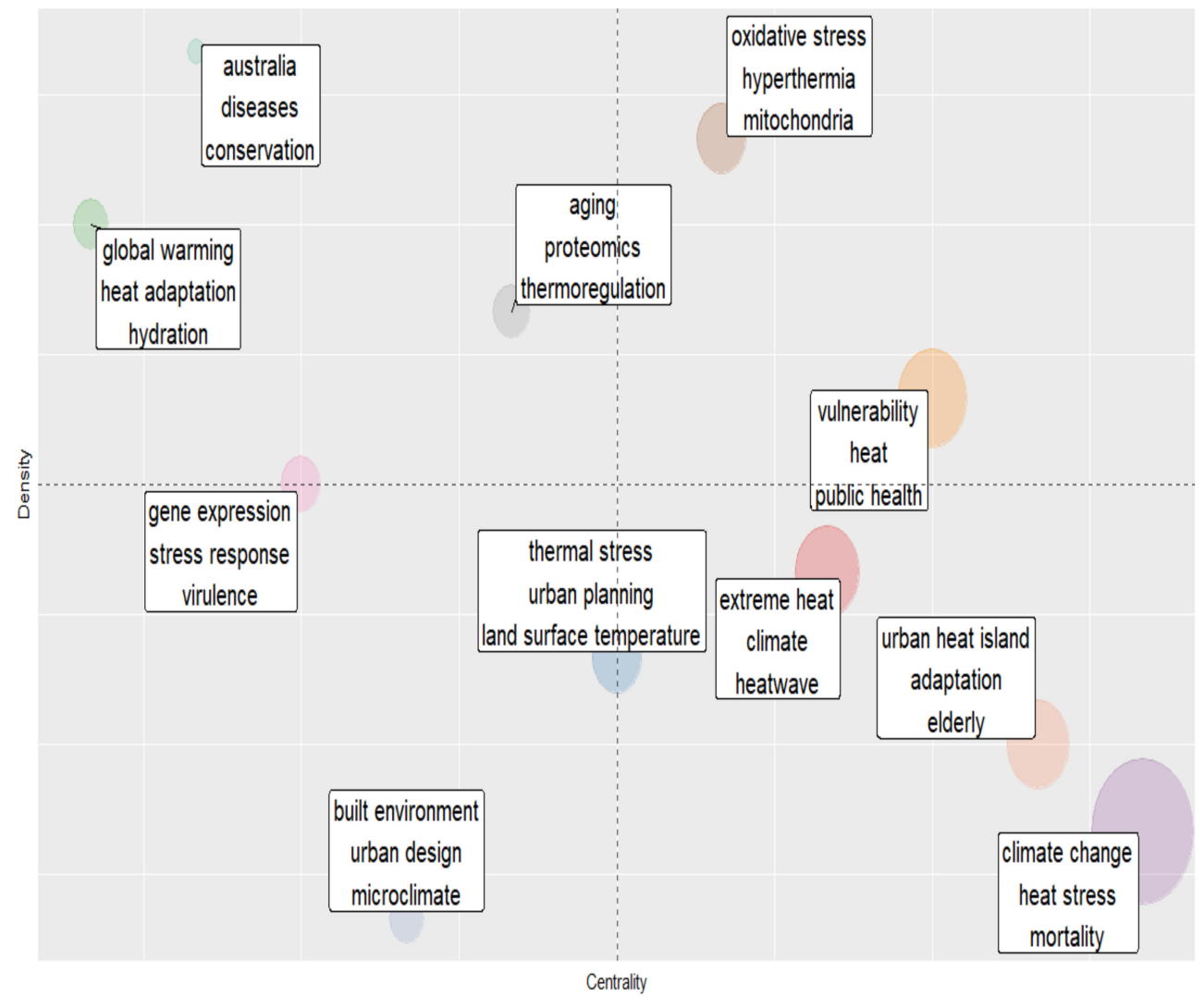

Figure 10. Thematic network of themes from analysis of scientific documents in heat stress and human health research published globally.

Based on Figure 11 for the African context, the themes in the lower right quadrant are the most basic, transversal, and relevant to the heat stress and human health research field. These themes include "heat stress", "developing countries", "Ebola", "climate change", "mortality", and "health". Similar to the global context, themes in this quadrant are weakly developed yet have excellent development potential and are integral to heat stress and human health research. The well-developed and integral themes (i.e., motor themes) include "humidity", "temperature", and "decaying muscles", situated in the upper right quadrant of Figure 11. The specialized themes, displayed in the upper left quadrant, are "Ebola virus" and "hemorrhagic fever", whereas "cortisol", "dehydration", "climate change", and "genotype" in the lower left quadrant are considered to be either emerging or disappearing themes, with low density and centrality.

In general, significant research themes are observed in the thematic map for Africa, as shown in Figure 11. These include those appearing in the upper left quadrant, which are weakly developed and marginal, with low centrality and low density. Such themes have well-developed internal ties but unimportant external ties. Researchers in Africa are 
paying close attention to motor themes in the upper right quadrant. These are at the core of research developments in heat stress and human health research in the African continent.

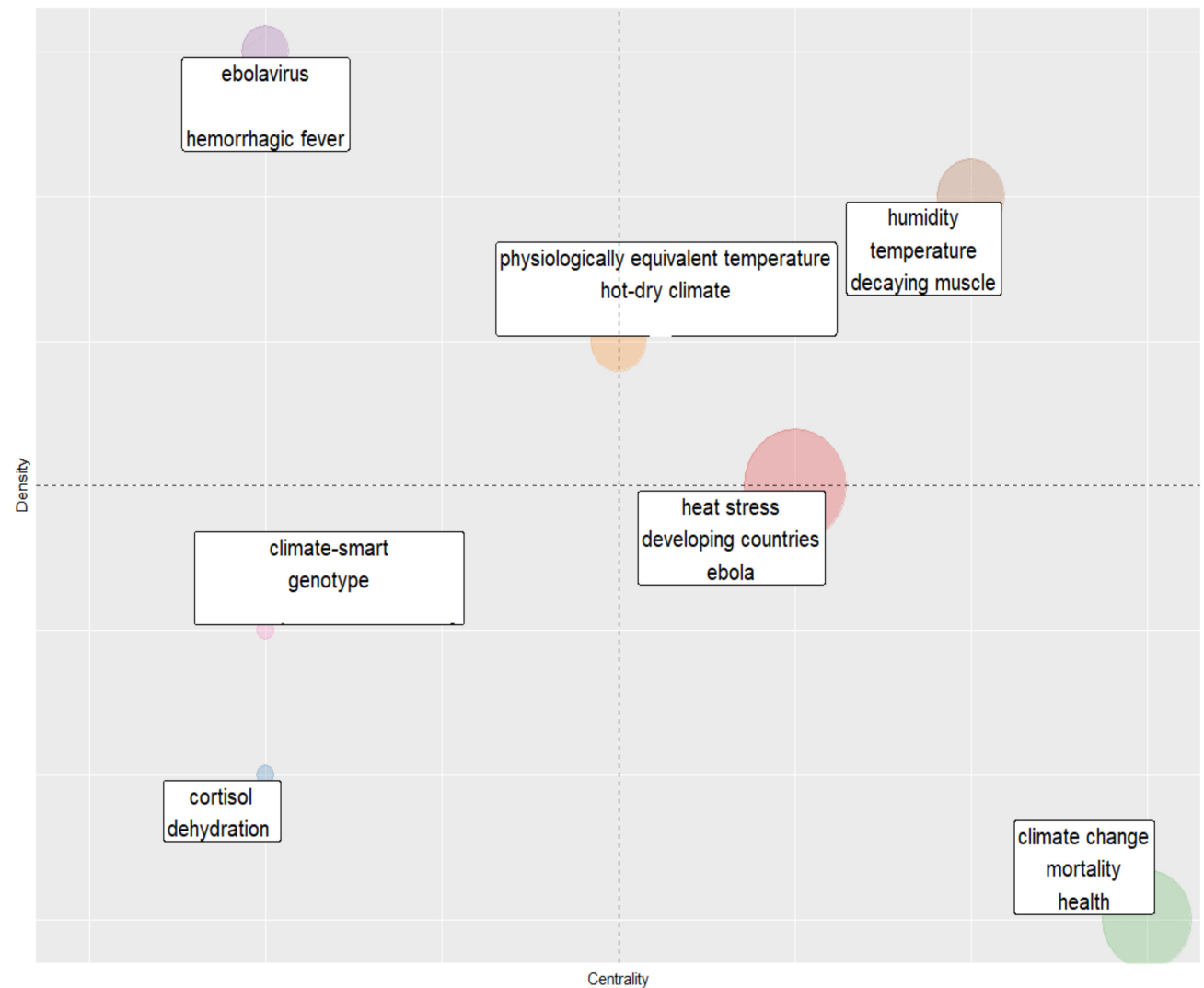

Figure 11. Thematic network of themes from analysis of scientific documents in heat stress and human health research published in Africa.

\section{Discussion}

Heat stress and human health research has progressed well and is generally now embedded within the sub-area of study within the field of climate change and human health Interest in the subject matter has been growing steadily since the early 1990s, following widespread attention on the human health consequences of climate change from scholars worldwide [49]. This is mirrored in the growing trend in the number of publications, as reported in this review study. Such an increasing trend is positively correlated with the increase in excessive heat and heatwave-induced mortality and morbidity incidences reported in many countries, both globally and across Africa. While severe heatwave events were recorded as early as 1950 [50], research publications on the subject remained limited globally, with relatively fewer publications prior to 2007. However, following significant heatwave events in various cities in the United States (i.e., the 1966 St Louis heatwave, the 1980 St Louis and Kansas City heatwave, the 1993 Philadelphia heatwave, and the 1995 Chicago heatwave [51]); in Europe (the 2003 European-wide heatwaves in England, Wales, France, Italy, and Portugal) [52]; as well as the 2009 southeastern Australia heatwave [53], there was a slight growth in the number of publications due to the need to understand the relationships between extreme heat exposure and related health impacts.

Notwithstanding this global interest, research in Africa is still nascent. Heat health scholarship remains comparatively sparse and fragmented, as illustrated by the number of publication outputs and the subsequent declining trend in the scientific publications observed in the past two years (2019 and 2020). Heat health-related outcomes are dependent on the local context [54]. However, the large volume of global scientific publications and the wealth of knowledge stemming from extensive research power from wealthier countries (i.e., the United States and Germany) does not necessarily reflect or address the heat health 
burden in African countries. This warrants the need for African countries to improve their research output and conduct research studies that will capture local conditions and release publications that will influence policy development to build resilience and mitigate unintended consequences of heat health risks in the continent.

The observed low scientific publication productivity might be attributed to various challenges, including a lack of funding, data availability, and the necessary expertise African researchers are confronted with $[55,56]$. On the contrary, these challenges are not usually found in developed countries. Hence, this research revealed that the United States is the most prolific country in heat health research, based on the publication output. This outcome is consistent with findings in other research fields, including sports entrepreneurship [57], climate change and infectious diseases [58], and medical data mining research [59]. Germany, which collaborates with the United States and two African countries, Nigeria and Burkina Faso, ranks second in publication output, followed by China. The close collaboration suggests that these countries share common scientific priorities and are better positioned to influence the course and direction of heat health research. The researcher's institutions affiliation was dominated by academic institutions mostly residing in the United States, including the University of Yale, and Columbia, Arizona State, and Washington Universities. This is followed by German institutions, including the Ludwig Maximilian University of Munich and the Research Centre for Artificial Intelligence (Deutsches Forschungszentrum für Künstliche Intelligenz). Likewise, the leading productive authors come from Germany and the United States, with 17 and 7 publications, respectively.

The country collaboration network analysis presented, in this review, indicated insufficient international research collaboration, yet this is highly needed in the African continent and it revealed the lack of cooperation among African countries. It is worrisome for neighboring nation-states who are more prone to issues that are unlikely to occur in isolation. This is a cause for concern since African countries, in most instances, face common cumulative challenges (i.e., a lack of or inaccessible data and funding) and development agenda needs. However, instead of working together in collaboration, they often work in silos, which subsequently affects the quality of research and limits research output, as demonstrated in this study. Most importantly, it impedes knowledge generation that can be fed into policy development processes. As research has shown, collaboration among researchers, students, and countries, in general, can help improve public health interventions, knowledge sharing and expertise, and can ultimately foster research development within countries and across regions [60]. Furthermore, it can be valuable in exchanging and accelerating heat health policy formulations critical for mitigation and adaptation strategies [42].

The perception that society's challenges are nuanced and interdependent suggests the need for strong collaborations and more interdisciplinary and transdisciplinary partnerships [61,62]. Transdisciplinary partnership seeks to leverage diverse approaches and experiences to integrate and transcend disciplinary bounds to advance scientific knowledge that will tackle pressing social, environmental, and health problems and, more importantly, reduce disparities [62]. Inputs from various stakeholders provide complementary insights and ensure the success and sustainability of efforts to reduce vulnerability to heat stress and mitigate adverse heat-related health outcomes [60]. A good example is the development of a heat health policy for the city of Adelaide in Australia [63], where multi-stakeholder consultations and involvement from different agencies led to the successful development and implementation of the adaptation strategy in response to the societal threats of heatwaves in that region. Akompab et al. [63] concluded that other regions of the world could adopt the same approach applied in their study to guide heatwave response plans. The current study revealed that South Africa had the biggest research contribution in Africa, and this has been reflected in the progress that is being made in the formulation of a national heat health plan called for by the National Climate Change Response Policy White Paper [41]. The reviewed literature on this topic did not reveal much development in other countries in Africa, suggesting the association of heat- health is currently an under-prioritized policy 
issue in Africa [64]. Furthermore, the lack of research productivity and collaboration at both the local and global levels exacerbates the status quo. Even though policy development might be influenced by numerous governance and institutional arrangements, as averred in the study by Akompab et al. [63], there is a high probability that if South African researchers had partnered more with local, continental collaborators and international partners, the development of the heat health plan in South Africa would have been at an advanced stage.

In terms of the keyword co-occurrence analysis, the red cluster, which is the largest in both the density visualization chart and the keyword co-occurrence analysis mapping, revealed Africa's research progress and focus, as defined by popular words like "health hazards", "public health", "risk factor", "evaluation", and "morbidity", which dominated a relatively large portion of publication production in this area. The thematic analysis further revealed emerging themes appearing in the right lower quadrant, covering specialized themes such as "urban planning", "thermal stress", "land surface temperature", "build in environment", "urban design", and "stress response", which are currently at the center of heat health research at the global level. The emerging themes in Africa are "dehydration" and the "cortisol" hormone, which has been found to increase with heat exposure [65]. While research themes have progressed dramatically at the global scale, capturing the current developments and advancements in heat health research, as evidenced by the diverse thematic areas in Figure 9, they are at a rather slow uptake in Africa. Basic themes, such as "vulnerability" (within population groups such as the elderly), "heat exposure", "exploration of effects of UHI on health", and "adaptation to extreme heat" are not represented under research themes in Africa. On the one hand, the results revealed the research gaps in Africa on this topic, and on the other, they provided new avenues for future research that need to be pursued by African researchers if the continent is to win the battle against climate changes and protect its citizens from associated heat health risks.

\section{Conclusions}

In this study, a bibliometric analysis of scientific publications in heat stress and human health research was conducted, with emphasis on the African continent. The study reviewed 463 global and 58 African scientific publications retrieved from the WoS and Scopus core databases, all released between 1968 and 2020. In this study, it is noted that while research on heat human health has gained momentum over the years, particularly on the global scale, the research within the heat health scientific domain has remained comparatively sparse and fragmented across Africa. The low research productivity in heat stress and human health subject field could be attributed to various factors, including a lack of funding, limitations to data accessibility and availability, unequal power dynamics, as well limited skilled human resources to undertake such research work on the continent. In addition, there are significant gaps in terms of heat stress and human health research in Africa compared to the global perspective. These research gaps provide opportunities for prospective researchers to carry out human health and heat stress-related research in Africa, focusing on numerous developmental areas such as (1) vulnerability assessments within and across demographic classes, including the elderly; (2) personal exposure and associated risks; (3), the UHI evaluation for urban environments; and (4) heat adaptation research, which will enable informed and targeted preventive actions that will limit future heat health impacts in the most vulnerable communities. While there have been many successful global research collaborations, such partnerships are very minimal among African countries, institutions, and researchers. There is a need for international organizations to ally with African researchers to strengthen research that will address heat health risks across the continent, subsequently influencing heat health policy developments and decision-making. An initiative such as the Global Heat Health Information Network (hereafter GHHIN), spearheaded by the $\mathrm{WMO} / \mathrm{WHO}$, could be used to bridge the gap in Africa and beyond borders. This is because the GHHIN advocates for the creation of alliances and interdisciplinary capacity-building and cooperation, including the sharing of 
resources for individual and administrative preparation, interinstitutional and interdisciplinary communication, and collaborations. In general, this review study contributes to building a body of research on heat stress and human health in Africa, thereby providing the necessary support in mitigating future impacts of heat stress-related illness under the changing climate.

Author Contributions: Conceptualization, K.P.N., J.O.B., C.M.B.; methodology, K.P.N., J.O.B., C.M.B., V.S.; software and visualization, K.P.N., J.O.B., C.M.B.; writing—original draft preparation; K.P.N.; supervision, V.S., J.O.B.; formal analysis, all authors; review and editing, all authors. All authors have read and agreed to the published version of the manuscript.

Funding: This research was funded by the Water Research Commission of South Africa, grant numbers WRCK5/C2019/2020-00020 and WRCK5/C2019/2020-00007.

Institutional Review Board Statement: Not applicable.

Informed Consent Statement: Not applicable.

Data Availability Statement: Not applicable.

Acknowledgments: We thank the Water Research Commission of South Africa for funding this research. The authors would also like to thank the editor and the reviewers for their constructive comments and contributions in improving this manuscript.

Conflicts of Interest: The authors declare no conflict of interest.

\section{Appendix A}

Table A1. A summary of 58 selected scientific publications on heat health studies conducted in Africa, 1968-2020.

\begin{tabular}{|c|c|c|c|}
\hline Reference & Corresponding Author & Year of Publication & Theme of the Study \\
\hline [46] & Hall, SA. & 1968 & $\begin{array}{l}\text { The Predicted 4-h Sweat Rate (P4SR) was used in this study to assess tolerable } \\
\text { limits of heat stress in outdoor work using data from a training center near } \\
\text { Dar es Salaam, Tanzania. }\end{array}$ \\
\hline [66] & Wyndham, C. & 1973 & $\begin{array}{l}\text { The study assessed the Wet Bulb Globe Temperature (WBGT) in the gold } \\
\text { mines in South Africa. The study indicated the curve of the probability of } \\
\text { acclimatized men reaching dangerously high } 4 \text { th-hour rectal temperatures, } \\
\text { indicating that there is less than a one in a million chance of this occurring in } \\
\text { acclimatized men below a WBGT of } 32^{\circ} \mathrm{C} \text {. }\end{array}$ \\
\hline [67] & Wyndham, C. & 1973 & $\begin{array}{l}\text { An experimental study in the acclimatized black mine workers in South } \\
\text { Africa. The study results showed substantial effects of the work rate upon the } \\
\text { body temperature if the WBGT rises above } 30^{\circ} \mathrm{C} \text {. Intensive mining } \\
\text { supervisors' training is advocated for the early detection of signs and } \\
\text { symptoms of heatstroke and associated corrective treatment underground. }\end{array}$ \\
\hline [68] & Wyndham, C. & 1973 & $\begin{array}{l}\text { To compare the occurrences of the different indices for estimating the } 4 \text { th-hour } \\
\text { rectal temperature, residual variances were measured on curves fitted to } \\
\text { 4th-hour rectal temperatures against heat stress indices from experiments on } \\
13 \text { highly acclimatized men subjected to } 45 \text { different combinations of } \\
5 \text { WBGTs. }\end{array}$ \\
\hline [69] & Wyndham, C. & 1974 & $\begin{array}{l}\text { The study gives an outline of the issues related to the severity of ambient heat } \\
\text { stress in South African gold mines where men operate underground: (1) } \\
\text { improved acclimatization to heat; (2) identification of heat intolerant men; (3) } \\
\text { specification of safe heat stress limits; (4) supplying mine managers with } \\
\text { knowledge on the thresholds of heat stress at which human output begins to } \\
\text { decline; and (5) adaptation of microclimate cooling systems for use in the gold } \\
\text { mining industry were among the five measures suggested. }\end{array}$ \\
\hline [70] & Ellis, $\mathrm{F}$. & 1976 & $\begin{array}{l}\text { This research study examined and analyzed data from the British army, the } \\
\text { Royal Navy, the Royal Air Force, the Indian Armed Forces, the US Army, and } \\
\text { forces engaged in Arab-Israeli conflicts, as well as data from South African } \\
\text { gold mining firms, Persian Gulf oil tankers, and civilians, all of which were in } \\
\text { the United States. The classification of heat illness, the sense of the terms used, } \\
\text { and the effect on acclimatized and non-acclimatized staff and other } \\
\text { disadvantaged civilian groups like the elderly and the very young were the } \\
\text { subjects of this research. }\end{array}$ \\
\hline
\end{tabular}


Table A1. Cont.

\begin{tabular}{|c|c|c|c|}
\hline Reference & Corresponding Author & Year of Publication & Theme of the Study \\
\hline$[71]$ & Kew, M. & 1976 & $\begin{array}{l}\text { Heat illnesses are almost entirely limited to the gold mining industry in South } \\
\text { Africa, where the high temperatures and humidity experienced in deep and } \\
\text { ultradeep level mining render heat illnesses a genuine threat. When high } \\
\text { ambient temperatures prevent heat dissipation by radiation or convection, } \\
\text { and sweat evaporation is reduced by high humidity, heatstroke may occur. }\end{array}$ \\
\hline$[72]$ & Martinson, M. & 1977 & $\begin{array}{l}\text { Due to the heat of auto compression applied to the air as it passes down } \\
\text { intake airways into underground workings, as well as the extensive usage of } \\
\text { water for dust suppression since the early century, a growing number of } \\
\text { mines have encountered hot and humid working conditions. Strenuous work } \\
\text { in oppressive climatic conditions, on the other hand, promotes high heat } \\
\text { stress, and, since 1924, heatstroke has become an endemic threat in some } \\
\text { Witwatersrand mines. Although heatstroke has a strong mortality rate, the } \\
\text { total death rate for all Witwatersrand mines has been less than } 1 \text { or } 2 \% \text { of the } \\
\text { overall death rate for all industrial deaths, while the death rate on a few } \\
\text { specific mines has been alarmingly high on occasion. }\end{array}$ \\
\hline$[73]$ & Shearer, A. S. & 1990 & $\begin{array}{l}\text { The experimental research study evaluated hydration and serum electrolyte } \\
\text { shifts in } 55 \text { black underground gold miners who had heat exhaustion, as well } \\
\text { as } 52 \text { surface and } 50 \text { underground employees who did not have any signs. }\end{array}$ \\
\hline$[74]$ & Beniston, $\mathrm{M}$. & 2002 & $\begin{array}{l}\text { This article provides an overview of a variety of issues concerning climate } \\
\text { change and human wellbeing. A brief description of climate change and its } \\
\text { anthropogenic causes is given, with particular attention paid to heat stress } \\
\text { and vector-borne diseases (e.g., malaria) in Africa, particularly in Rwanda } \\
\text { and Zambia. }\end{array}$ \\
\hline
\end{tabular}

[75] Donoghue, A.

[76] Ali-toudert, F.
An experimental study conducted over 18 years between 1983 and 2001, assessing heat illnesses in the mining industry in South Africa and Australia. The study established that heat illnesses increased during the summer months. High incidences of heat illness occurred most frequently in stone mills, metal mills, and underground metal mines.

An experimental study assessed aspects of outdoor thermal comfort in a hot and dry climate. The study measured temperature, air humidity, and wind speed at different urban streets in Beniisguen, Algeria, during the summer of 2003.

A look at the findings of the Stern Report on extreme weather and its impact on human health and wellbeing. The study indicates the rising temperatures would exacerbate malnutrition and heat stress, as well as facilitate the spread of vector-borne diseases like malaria and dengue fever in places where they are currently absent.

An analysis of the Avian Flu outbreaks that began in geese in the Chinese province of Guangdong in 1996 and spread due to intensified heat stress conditions. The virus was first related to human infection in Hong Kong in 1997 before spreading to Eurasia, Europe, the Middle East, and Africa in $2005 / 2006$.

The study explored the reality and fiction around human heat stress in sports by analyzing previous scientific results, some of which present contradicting findings on heatstroke and other heat-related illnesses.

A book chapter on regional climate model simulations that projects dryer conditions, near-surface warming, and heat stress will intensify. The chapter highlights the need for more complex scenarios to assess the human influence on the African climate.

Using a questionnaire, an epidemiological analysis assesses occurrences of common health hazards among male and female travelers. Female travelers were found to be more vulnerable to different health threats, with coughs being the most common symptom (attack incidence of $51 \%$ ), accompanied by headache, heat stress, and fever. Quite a few passengers experienced diarrhea and vomiting.

The research study focused on ensembles of long-term temporary climate change studies that forecast the African climate's potential course under three scenarios. Over much of tropical Africa, the findings showed substantial surface heating and a slowing of the hydrological cycle, resulting in increased heat stress and longer dry spells. 
Table A1. Cont.

\begin{tabular}{|c|c|c|c|}
\hline Reference & Corresponding Author & Year of Publication & Theme of the Study \\
\hline [83] & Hyatt, O.M. & 2010 & $\begin{array}{l}\text { The research study utilized gridded data to measure occupational heat } \\
\text { intensity for tropical and sub-tropical countries using the WBGT heat index, } \\
\text { focusing on workplaces without cooling systems. The easily interpreted maps } \\
\text { provide essential information for public health authorities. }\end{array}$ \\
\hline [84] & Tiller, D.K. & 2010 & $\begin{array}{l}\text { The research presents the findings of a study that assessed the cumulative } \\
\text { impact of noise and temperature on human thermal comfort and task } \\
\text { efficiency. The results indicated that males and females have different } \\
\text { responses to thermal and acoustic conditions. }\end{array}$ \\
\hline [85] & Scovronick, N. & 2012 & $\begin{array}{l}\text { The research study measured provincial-level dose-response relationships, } \\
\text { relative risks, attributable fractions, and mortality burdens for heat and cold } \\
\text { through evaluating seven housing environments. The results revealed that a } \\
\text { policy scenario prioritizing informal housing displacement would result in } \\
\text { lower possible mortality burdens than one prioritizing the replacement of } \\
\text { traditional dwellings. }\end{array}$ \\
\hline [86] & Bourdt, G.W. & 2012 & $\begin{array}{l}\text { The study predicted the spread of Nassella neesiana in six different climate } \\
\text { scenarios, namely eastern and southwestern Africa, North America's } \\
\text { northwest coast and southeastern United States, the United Kingdom, France, } \\
\text { Italy, Spain, Australia, and New Zealand more generally. Temperature } \\
\text { increases resulted in fatal heat stress and the spread of N. neesiana. }\end{array}$ \\
\hline [87] & Myers, S.S. & 2013 & $\begin{array}{l}\text { The study explored what is understood regarding the public health and } \\
\text { operation of natural environments, such as changes in heat stress conditions. } \\
\text { The study suggests that these changes influence human health in several } \\
\text { respects. The study identified several gaps and limitations in previous } \\
\text { research and suggested a more structured and rigorous approach to applied } \\
\text { research in this area. }\end{array}$ \\
\hline
\end{tabular}

[88] Liu, K. 2013
Leone, $\mathrm{M}$.
Garland, R.M.
[33]

Kjellstrom, T.

Zhao, Y.
The study assessed trehalose, a predominant sugar in mosquito hemolymphs, that not only provides energy but also protects the mosquito against desiccation and extreme heat stress. The study established that Anopheles gambiae expression is induced by environmental stresses, such as low humidity or elevated temperature, that result in heat stress conditions.

The study quantified the effect of summer temperatures in southeast Mediterranean cities and compared it with European cities around the Mediterranean basin, evaluating city characteristics that explain between-city heterogeneity. Young populations in southeastern Mediterranean cities were found to be the most vulnerable to high temperatures, which creates the need to strengthen research and public health efforts in these Mediterranean countries.

The review of South Africa's White Paper. Identified potential health challenges for South Africa, such as vector- and water-borne pathogens, as well as heat stress, were assessed. The study further reviewed the national climate change and health adaptation program, which expanded on several health issues as well as associated social risk factors, including accommodation and settlements. The study revealed that one of the guiding principles for executing the strategy was community engagement, mainly because behavioral modification is likely to be necessary for adaptation and coping strategies.

The study looks at heat stress in vast workplaces like mines, irrigation, construction, and quarries, as well as outdoor services, factories, and workshops. It is well established that occupational heat stress is becoming more of a concern, especially in the many workplaces that lack efficient cooling systems. South Africa, for example, would be the worst hit.

The research uses three heat stress metrics to assess the evolution of heat stress. The research focused on 21 different general circulation models (GCMS), and it revealed that the increased vulnerability of human societies to heat stress is one of the potential outcomes of global warming with negative implications on health and labor power.

The study determined the hydration status and fluid intake of socio-economically disadvantaged male adolescent soccer players during training. The study revealed that many did not drink or drank insufficient amounts during and after training. Approximately a quarter were severely dehydrated. 
Table A1. Cont.

\begin{tabular}{|c|c|c|c|}
\hline Reference & Corresponding Author & Year of Publication & Theme of the Study \\
\hline [93] & Potter, A.W. & 2015 & $\begin{array}{l}\text { The experimental study used a sweating thermal manikin to measure the } \\
\text { thermal (RCT), and evaporative resistance (RET) of the five commonly used } \\
\text { Personal Protective Clothing (PPC) to aid in the prevention of heat stress for } \\
\text { healthcare workers wearing PPE during Ebola outbreak response in } \\
\text { West Africa. }\end{array}$ \\
\hline [36] & Bidassey-Manilal, S. & 2016 & $\begin{array}{l}\text { The experimental study established that classrooms made of prefabricated } \\
\text { asbestos sheeting with a corrugated iron roof and converted shipping } \\
\text { container had consistently higher indoor temperatures than } \\
\text { concrete classrooms. }\end{array}$ \\
\hline [94] & Pozio, E. & 2016 & $\begin{array}{l}\text { The study reported that the normal cycle of trichinella taxa circulating in cold } \\
\text { climates would be impacted by rising temperatures, declining humidity and } \\
\text { snow cover, and increasing heat stress exposure. }\end{array}$ \\
\hline [95] & Bailey, M.S. & 2016 & $\begin{array}{l}\text { This study evaluated how medical assets were deployed during a short-notice } \\
\text { contingent activity in West Africa, which is prone to climatic conditions, } \\
\text { including heat stress, responsible for various health problems in the region. }\end{array}$ \\
\hline [96] & Coca, A. & 2017 & $\begin{array}{l}\text { The experimental research assessed humans' physiological and subjective } \\
\text { reactions to constant light exercise in environments close to those present in } \\
\text { West Africa when wearing three distinct styles of PPE. The study suggests } \\
\text { that heat stress and PPE training as well as the introduction of a work-to-rest } \\
\text { ratio, will eliminate exhaustion and potential heat stress problems. }\end{array}$ \\
\hline [97] & Stacey, M.J. & 2018 & $\begin{array}{l}\text { The role of copeptin secretion in providing knowledge about fluid balance, } \\
\text { thermal strain, and health risks linked to imminent heat stress risks and } \\
\text { associated heat-related illnesses was investigated in this experimental study. }\end{array}$ \\
\hline [98] & Asefi-Najafabady, S. & 2018 & $\begin{array}{l}\text { According to this projection study, temperature extremes and heat threats } \\
\text { could escalate from } 7 \text { to } 269 \text { times above current levels. The most critical rises } \\
\text { are seen in Kenya's north and west, as well as areas of Uganda and the } \\
\text { Democratic Republic of Congo. }\end{array}$ \\
\hline [99] & Newth, D. & 2018 & $\begin{array}{l}\text { The global and regional changes in WBGT were calculated to assess the } \\
\text { environmental heat stress. The results of simulations of the four } \\
\text { representative concentration pathways (RCPS) from the coupled model } \\
\text { intercomparison project phase } 5 \text { (CMIP5) were used in the analysis. }\end{array}$ \\
\hline [100] & Coffel, E.D. & 2018 & $\begin{array}{l}\text { In this study, as measured by the WBGT, heat stress is expected to rise by a } \\
\text { factor of } 5-10 \text { as a consequence of global temperature and humidity changes, } \\
\text { with } 150-750 \text { million person-days of exposure. }\end{array}$ \\
\hline [101] & Ahmadalipour, A. & 2018 & $\begin{array}{l}\text { The WBGT heat index was calculated using daily climate data from } \\
17 \text { fine-resolution regional climate models (RCMS) around the Mena zone to } \\
\text { assess the probability of death from extreme heat stress for people over } 65 \\
\text { years. If no climate change mitigation is introduced, the mortality risk will } \\
\text { climb to } 8-20 \text { times that of the historical period. }\end{array}$ \\
\hline [102] & Abera, T.A. & 2018 & $\begin{array}{l}\text { A 16-year time series of remotely sensed environmental evidence (2001-2016) } \\
\text { was used to determine how the relationship of rainfall-vegetation impacts of } \\
\text { drought conditions is aggravated by heat stress. }\end{array}$ \\
\hline [103] & Quinn, T. & 2018 & $\begin{array}{l}\text { Using thermal manikin simulation and human testing, this experimental } \\
\text { research study assessed the physiological effect and heat perception of four } \\
\text { different personal cooling devices under impermeable PPE during } \\
\text { low-intensity exercise in a hot and humid setting. According to the findings, } \\
\text { using a personal cooling system in combination with impermeable PPE will } \\
\text { help reduce the physiological and perceptual effects of heat stress. }\end{array}$ \\
\hline [104] & Ekiti, M.E. & 2018 & $\begin{array}{l}\text { The aim of this study was to determine the prevalence of chronic kidney } \\
\text { disease (CKD) among Mbandjock sugarcane plantation workers in Cameroon, } \\
\text { as well as the factors that contribute to it. The prevalence of CKD was } \\
\text { observed to be lower than the national average, owing to preventative steps } \\
\text { taken to reduce heat stress and dehydration. }\end{array}$ \\
\hline [105] & Den Boon, $S$. & 2018 & $\begin{array}{l}\text { During the 2014-2016 Ebola epidemic in West Africa, the usage of personal } \\
\text { protective equipment (PPE) to shield health workers from Ebola virus disease } \\
\text { was linked to severe heat stress and dehydration. The research suggested that } \\
\text { recommendations be given to direct the successful use of PPE. }\end{array}$ \\
\hline
\end{tabular}


Table A1. Cont.

\begin{tabular}{|c|c|c|c|}
\hline Reference & Corresponding Author & Year of Publication & Theme of the Study \\
\hline [106] & Kapwata, T. & 2018 & $\begin{array}{l}\text { To measure the impact of heat stress, this research looked at the connection } \\
\text { between indoor and outdoor temperatures in a rural, suburban setting in a } \\
\text { current atmosphere and a colder-than-expected future climate. }\end{array}$ \\
\hline [107] & Sylla, M.B. & 2018 & $\begin{array}{l}\text { Heat stress threats are most remarkable in the Sahel and Western Sahara } \\
\text { deserts from the month of June to August, where the majority of the } \\
\text { population is at risk of dangerous heat stress, during which everybody, } \\
\text { particularly workers, feels discomfort and is prone to heat cramps and } \\
\text { heat exhaustion. }\end{array}$ \\
\hline [108] & Kadzere, C.T. & 2018 & $\begin{array}{l}\text { Mounting climate change impacts, such as heat stress, pose multidisciplinary } \\
\text { problems that include integrated cross-discipline study, expansion, and } \\
\text { preparation to have holistic solutions. }\end{array}$ \\
\hline [109] & Wessling, E.G. & 2018 & $\begin{array}{l}\text { Chimpanzees, one of humanity's nearest relatives, were used in an } \\
\text { experiment to see how much seasonal variability in energy balance or } \\
\text { thermoregulation (dehydration and heat exposure) impacts chimps live in an } \\
\text { extreme savanna habitat. }\end{array}$ \\
\hline [110] & Yezli, S. & 2019 & $\begin{array}{l}\text { The study investigated the awareness, behavior, and experience of } \\
\text { heat-related illnesses and how to avoid them during the } 2017 \text { HAJJ pilgrimage. } \\
\text { The study established a lack of hydration and a refusal to use any preventative } \\
\text { steps or adjust the HAJJ activities plan, depending on the weather. }\end{array}$ \\
\hline
\end{tabular}

A literature review study on the consequences of excessive heat exposure and health concerns among outdoor workers as well as the related effects on productivity and occupational safety in tropical developing countries, with an

[111] Moda, H.M. Capon, A. Liu, X. Rasilla, D.

2019

[115] Mastrucci, A. Jagarnath, M emphasis on sub-Saharan Africa, where such studies are limited. Other indirect health risks correlated with increasing heat among this population include vulnerability to hazardous chemicals and other vector-borne diseases, in addition to the direct consequences of excessive heat exposure.

The Lancet reported heatwaves are becoming more frequent, intense, and long-lasting as Earth warms. According to the report, so far this year, several countries have broken all-time high-temperature records. The month of June was the hottest month on record for Europe, with average temperatures $2{ }^{\circ} \mathrm{C}$ above usual due to an early and extreme heatwave. On June 28, France set a new national temperature high of $45.9^{\circ} \mathrm{C}$. A second big heatwave in a month hit Germany, Belgium, and the Netherlands July 24-25, setting fresh all-time records on two consecutive days. This year, India and Pakistan were also scorched by a sustained extreme heatwave, with temperatures in several areas exceeding $45^{\circ} \mathrm{C}$ for several weeks. On June 10 , Delhi witnessed its hottest day of the month, with a temperature of $48^{\circ} \mathrm{C}$.

The study examined the relations between the preceding 3-month standardized precipitation index (SPI) and the number of hot days indicated by the surface air temperature (NHD-TX) and the wet bulb globe temperature (NHD-WX). The findings revealed that there could be local input between surface moisture and oppressive hot extremes, modulating the intolerable heat stress in some regions of the tropics.

Due to the excess heat generated by UHI as well as poorer air quality, heatwaves pose additional threats to urban spaces. The lack of wind-driven cooling causes severe thermal stress in the city during the day. Because of the higher-than-normal volume of pollutants coming from northern Africa during heatwaves, the air quality deteriorates.

The study estimated, using the variable degree days (VDD) method, the extent of populations potentially exposed to heat stress as well as the energy demand required to meet these cooling needs, accounting for spatially explicit climate, housing types, access to electricity, and air conditioning ownership.

To classify areas of possible future heat stress danger in the Durban (eThekwini) metropolitan region, the study assessed current and projected future heat risk, expressed as a heat stress sensitivity index based on high-resolution climate change predictions, as well as a social vulnerability index.

[117] Yengoh, G.T.

Using data from general circulation models, the distribution of future heat stress risks based on WBGT was evaluated to see if it will impact smallholder farmers' capacity to conduct agricultural activities. 
Table A1. Cont.

\begin{tabular}{|c|c|c|c|}
\hline Reference & Corresponding Author & Year of Publication & Theme of the Study \\
\hline [118] & Cook, T.R. & 2020 & $\begin{array}{l}\text { Under potential climate simulations, the research study modeled } \\
\text { thermoregulatory responses arising from high temperatures and hot } \\
\text { conditions that have devastating consequences on animals, contributing to } \\
\text { mass mortalities. }\end{array}$ \\
\hline [119] & Matallah, M.E. & 2020 & $\begin{array}{l}\text { In the heart of the Tolga palm grove and in different urban settlements, the } \\
\text { analysis measured thermal comfort in the Tolga oasis complex and checked } \\
\text { the validity of the "oasis influence" definition. The findings show that the } \\
\text { oases palm grove has the highest rate of heat stress (Physiologically Equal } \\
\text { Temperature (PET) index). }\end{array}$ \\
\hline$[120]$ & Temple, D. & 2020 & $\begin{array}{l}\text { This study outlined the animal welfare problems most likely to be found in } \\
\text { extensive systems, centered on the four environmental animal welfare realms } \\
\text { of heat stress, diet, health, and actions. In terms of climate conditions, food } \\
\text { safety, and connectivity, comprehensive networks are incredibly complex } \\
\text { and heterogeneous. }\end{array}$ \\
\hline
\end{tabular}

\section{References}

1. Lundgren, K.; Kuklane, K.; Gao, C.; Holmér, I. Effects of heat stress on working populations when facing climate change. Ind. Health 2013, 51, 3-15. [CrossRef] [PubMed]

2. Sellers, S. Gender and Climate Change: A Closer Look at Existing Evidence; Global Gender and Climate Alliance: New York, NY, USA, 2016.

3. World Health Organization. COP24 special report health and climate change. 2018. Available online: https://apps.who.int/iris/ bitstream/handle/10665/276405/9789241514972-eng.pdf (accessed on 3 February 2021).

4. IPCC Climate Change 2014: Synthesis Report. In Contribution of Working Groups I, II, and III to the Fifth Assessment Report of the Intergovernmental Panel on Climate Change; IPCC: Geneva, Switzerland, 2014.

5. McMichael, A.; Campbell-Lendrum, D.; Ebi, K.; Githeko, A.; Scheraga, J.; Woodward, A. Climate Change and Human Health: Risks and Responses; World Health Organization: Geneva, Switzerland, 1996.

6. Kim, K.-H.; Kabir, E.; Ara Jahan, S. A review of the consequences of global climate change on human health. J. Environ. Sci. Health C Environ. Carcinog. Ecotoxicol. Rev. 2014, 32, 299-318. [CrossRef] [PubMed]

7. Intergovernmental Panel on Climate Change (IPCC). Climate Change 2014: Impacts, Adaptation and Vulnerability. In Working Group II Contribution to the Fifth Assessment Report; 2014. Available online: https://www.ipcc.ch/report/ar5/wg2/ (accessed on 7 May 2021).

8. World Health Organization. Climate Change and Health. 2017. Available online: http://www.who.int/mediacentre/factsheets/ fs266/en/ (accessed on 3 February 2021).

9. Campbell, S.; Remenyi, T.A.; White, C.J.; Johnston, F.H. Heatwave and health impact research: A global review. Health Place 2018, 53, 210-218. [CrossRef]

10. Meehl, G.A.; Stocker, T.F.; Collins, W.D.; Friedlingstein, P.; Gaye, T.; Gregory, J.M.; Kitoh, A.; Knutti, R.; Murphy, J.M.; Noda, A.; et al. Global climate projections. In IPCC, 2007: Climate Change 2007: The Physical Science Basis. Contribution of Working Group I to the Fourth Assessment Report of the Intergovernmental Panel on Climate Change; Solomon, S., Qin, D., Manning, M., Chen, Z., Marquis, M., Averyt, K.B., Tignor, M., Miller, H.L., Eds.; Cambridge University Press: Cambridge, UK, 2007.

11. Engelbrecht, F.; Adegoke, J.; Bopape, M.-J.; Naidoo, M.; Garland, R.; Thatcher, M.; McGregor, J.; Katzfey, J.; Werner, M.; Ichoku, C.; et al. Projections of rapidly rising surface temperatures over Africa under low mitigation. Environ. Res. Lett. 2015, 10, 085004. [CrossRef]

12. Polioptro, F.M.-A.; Bandala, E.R. Heat Waves: Health Effects, Observed Trends and Climate Change. Extreme Weather 2018. [CrossRef]

13. Perkins, S.E.; Alexander, L.V.; Nairn, J.R. Increasing frequency, intensity and duration of observed global heatwaves and warm spells. Geophys. Res. Lett. 2012, 39, 20714. [CrossRef]

14. Chen, X.; Li, N.; Liu, J.; Zhang, Z.; Liu, Y. Global heatwave hazard considering humidity effects during the 21st century. Int. J. Environ. Res. Public Health 2019, 16, 1513. [CrossRef]

15. Nangombe, S.; Zhou, T.; Zhang, W.; Wu, B.; Hu, S.; Zou, L.; Li, D. Record-breaking climate extremes in Africa under stabilized $1.5^{\circ} \mathrm{C}$ and $2{ }^{\circ} \mathrm{C}$ global warming scenarios. Nat. Clim. Chang. 2018, 8, 375-380. [CrossRef]

16. Welborn, L. Africa and climate change-Projecting vulnerability and adaptive capacity ISS Africa Rep. 2018. Available online: https:/ /issafrica.org/research/africa-report/africa-and-climate-change-projecting-vulnerability-and-adaptive-capacity (accessed on 7 May 2021).

17. Rohat, G.; Flacke, J.; Dosio, A.; Dao, H.; van Maarseveen, M. Projections of human exposure to dangerous heat in African cities under multiple socio-economic and climate scenarios. Earth Future 2019, 7, 528-546. [CrossRef]

18. Marcotullio, P.J.; Keßler, C.; Fekete, B.M. The future urban heat-wave challenge in Africa: Exploratory analysis. Glob. Environ. Chang. 2021, 66, 102190. [CrossRef]

19. Koubi, V. Sustainable Development Impacts of Climate Change and Natural Disaster; Background Paper Prepared for Sustainable Development Outlook 2019 of United Nations Department of Economic and Social Affairs; UN: New York, NY, USA, 2019. 
20. Robine, J.M.; Cheung, S.L.K.; Le Roy, S.; Van Oyen, H.; Griffiths, C.; Michel, J.P.; Herrmann, F.R. Death toll exceeded 70,000 in Europe during the summer of 2003. Comptes Rendus. Biol. 2008, 331, 171-178. [CrossRef]

21. Rebetez, M.; Dupont, O.; Giroud, M. An analysis of the July 2006 heatwave extent in Europe compared to the record year of 2003. Theor. Appl. Clim. 2008, 95, 1-7. [CrossRef]

22. Knowlton, K.; Rotkin-Ellman, M.; King, G.; Margolis, H.G.; Smith, D.; Solomon, G.; Trent, R.; English, P. The 2006 California Heat Wave: Impacts on Hospitalizations and Emergency Department Visits. Environ. Health Perspect. 2009, 117, 61-67. [CrossRef] [PubMed]

23. Barriopedro, D.; Fischer, E.M.; Luterbacher, J.; Trigo, R.M.; García-Herrera, R. The Hot Summer of 2010: Redrawing the Temperature Record Map of Europe. Science 2011, 332, 220-224. [CrossRef] [PubMed]

24. Kravchenko, J.; Abernethy, A.P.; Fawzy, M.; Lyerly, H.K. Minimization of Heatwave Morbidity and Mortality. Am. J. Prev. Med. 2013, 44, 274-282. [CrossRef] [PubMed]

25. Takaro, T.K.; Henderson, S.B. Climate change and the new normal for cardiorespiratory disease. Can. Respir. J. 2015, 22, 52-54. [CrossRef]

26. Wang, Y.-C.; Lin, Y.-K. Association between Temperature and Emergency Room Visits for Cardiorespiratory Diseases, Metabolic Syndrome-Related Diseases, and Accidents in Metropolitan Taipei. PLoS ONE 2014, 9, e99599. [CrossRef]

27. Hollowell, D.R. Perceptions of, and reactions to, environmental heat: A brief note on issues of concern in relation to occupational health. Glob. Health Action 2010, 3, 3. [CrossRef]

28. Lucas, R.A.I.; Epstein, Y.; Kjellstrom, T. Excessive occupational heat exposure: A significant ergonomic challenge and health risk for current and future workers. Extreme Physiol. Med. 2014, 2, 14.

29. Gun, R. Deaths in Australia from Work-Related Heat Stress, 2000-2015. Int. J. Environ. Res. Public Health 2019, 16, 3601. [CrossRef]

30. Vaidyanathan, A.; Malilay, J.; Schramm, P.; Saha, S. Heat-Related Deaths-United States, 2004-2018. MMWR. Morb. Mortal. Wkly. Rep. 2020, 69, 729-734. [CrossRef] [PubMed]

31. Kjellstrom, T.; Holmer, I.; Lemke, B. Workplace heat stress, health and productivity-An increasing challenge for low and middle-income countries during climate change. Glob. Health Action 2009, 2. [CrossRef] [PubMed]

32. Kjellstrom, T. Impact of Climate Conditions on Occupational Health and Related Economic Losses. Asia Pac. J. Public Health 2016, 28, 28S-37S. [CrossRef] [PubMed]

33. Kjellstrom, T.; Lemke, B.; Hyatt, O.; Otto, M. Climate change and occupational health: A South African perspective. South Afr. Med J. 2014, 104, 586. [CrossRef] [PubMed]

34. Kjellstrom, T.; Briggs, D.; Freyberg, C.; Lemke, B.; Otto, M.; Hyatt, O. Heat, Human Performance, and Occupational Health: A Key Issue for the Assessment of Global Climate Change Impacts. Annu. Rev. Public Health 2016, 37, 97-112. [CrossRef]

35. Bidassey-Manilal, S.; Wright, C.Y.; Kapwata, T.; Shirinde, J. A Study Protocol to Determine Heat-Related Health Impacts among Primary Schoolchildren in South Africa. Int. J. Environ. Res. Public Health 2020, 17, 5531. [CrossRef]

36. Bidassey-Manilal, S.; Wright, C.Y.; Engelbrecht, J.C.; Albers, P.N.; Garland, R.M.; Matooane, M. Students' Perceived Heat-Health Symptoms Increased with Warmer Classroom Temperatures. Int. J. Environ. Res. Public Health 2016, 13, 566. [CrossRef]

37. Dapi, L.N.; Rocklöv, J.; Nguefack-Tsague, G.; Tetanye, E.; Kjellstrom, T. Heat impact on schoolchildren in Cameroon, Africa: Potential health threat from climate change. Glob. Health Action 2010, 3, 5610. [CrossRef] [PubMed]

38. McCarthy, M.P.; Best, M.J.; Betts, R.A. Climate change in cities due to global warming and urban effects. Geophys. Res. Lett. 2010, 37, 09705. [CrossRef]

39. Chapman, S.; Watson, J.E.M.; Salazar, A.; Thatcher, M.; McAlpine, C.A. The impact of urbanization and climate change on urban temperatures: A systematic review. Landsc. Ecol. 2017, 32, 1921-1935. [CrossRef]

40. Berry, P.; Yusa, A.; Morris-Oswald, T.; Rogaeva, A. Heat Alert and Response Systems in Urban and Rural Communities in Canada. Chang. Adapt. Socio-Ecological Syst. 2014, 1, 84-97. [CrossRef]

41. Higgins, J.P. Cochrane Handbook for Systematic Reviews of Interventions; Version 5.0.1; The Cochrane Collaboration: London, UK, 2008; Available online: :http:/ / www.cochrane-handbook.org (accessed on 7 May 2021).

42. Gao, C.; Kuklane, K.; Östergren, P.-O.; Kjellstrom, T. Occupational heat stress assessment and protective strategies in the context of climate change. Int. J. Biometeorol. 2018, 62, 359-371. [CrossRef] [PubMed]

43. Zupic, I.; C``ater, T. Bibliometric methods in management and organization. Organ. Res. Methods 2015, 18, 429-472. [CrossRef]

44. Aria, M.; Cuccurullo, C. bibliometrix: An R-tool for comprehensive science mapping analysis. J. Inf. 2017, 11, 959-975. [CrossRef]

45. Van Eck, N.; Waltman, L. Software survey: VOSviewer, a computer program for bibliometric mapping. Scientometrics 2009, 84, 523-538. [CrossRef] [PubMed]

46. Hall, S.A. Heat Stress in Outdoor Manual Workers in East Africa. Ergonomics 1971, 14, 91-94. [CrossRef]

47. Waltman, L.; van Eck, N.J.; Noyons, E.C.M. A unified approach to mapping and clustering of bibliometric networks. J. Inf. 2010, 4, 629-635. [CrossRef]

48. Cobo, M.; López-Herrera, A.; Herrera-Viedma, E.; Herrera, F. An approach for detecting, quantifying, and visualizing the evolution of a research field: A practical application to the Fuzzy Sets Theory field. J. Inf. 2011, 5, 146-166. [CrossRef]

49. Bell, M.; Greenberg, M.R. Climate Change and Human Health: Links Between History, Policy, and Science. Am. J. Public Health 2018, 108, S54-S55. [CrossRef] [PubMed]

50. Russo, S.; Sillmann, J.; Fischer, E.M. Top ten European heat-waves since 1950 and their occurrence in the coming decades. Environ. Res. Lett. 2015, 10, 124003. [CrossRef] 
51. Whitman, S.; Good, G.; Donoghue, E.R.; Benbow, N.; Shou, W.; Mou, S. Mortality in Chicago attributed to the July 1995 heat wave. Am. J. Public Health 1997, 87, 1515-1518. [CrossRef]

52. Kosatsky, T. The 2003 European heat waves. Eurosurveillance 2005, 10, 3-4. [CrossRef]

53. Nitschke, M.; Tucker, G.R.; Hansen, A.L.; Williams, S.; Zhang, Y.; Bi, P. Impact of two recent extreme heat episodes on morbidity and mortality in Adelaide, South Australia: A case-series analysis. Environ. Health 2011, 10, 42. [CrossRef] [PubMed]

54. Sewe, M.O.; Bunker, A.; Ingole, V.; Egondi, T.; Åström, D.O.; Hondula, D.M.; Rocklöv, J.; Schumann, B. Estimated Effect of Temperature on Years of Life Lost: A Retrospective Time-Series Study of Low-, Middle-, and High-Income Regions. Environ. Health Perspect. 2018, 126, 017004. [CrossRef] [PubMed]

55. Badr, M.Z. Challenges Facing Scientific Research in Developing Countries: 2. Environment and Resources. Egypt. J. Basic Clin. Pharmacol. 2018, 8, 1-2. [CrossRef] [PubMed]

56. Acharya, K.P.; Pathak, S. Applied Research in Low-Income Countries: Why and How? Front. Res. Metrics Anal. 2019, 4. [CrossRef]

57. González-Serrano, M.H.; Hervás, J.C.; Pérez-Campos, C.; Calabuig-Moreno, F. The importance of developing the entrepreneurial capacities in sport sciences university students. Int. J. Sport Policy Politics 2017, 9, 625-640. [CrossRef]

58. Sweileh, W.M. Bibliometric analysis of peer-reviewed literature on climate change and human health with an emphasis on infectious diseases. Glob. Health 2020, 16, 1-17. [CrossRef] [PubMed]

59. Hu, Y.; Yu, Z.; Cheng, X.; Luo, Y.; Wen, C. A bibliometric analysis and visualization of medical data mining research. Med. 2020, 99, e20338. [CrossRef]

60. Wilhelmi, O.; Hayden, M. Reducing vulnerability to extreme heat through interdisciplinary research and stakeholder en-gagement. In Extreme Weather, Health, and Communities; Springer: Berlin/Heidelberg, Germany, 2016; pp. 165-186.

61. Nyström, M.E.; Karltun, J.; Keller, C.; Andersson, G.B. Collaborative and partnership research for improvement of health and social services: Researcher's experiences from 20 projects. Health Res. Policy Syst. 2018, 30, 46. [CrossRef] [PubMed]

62. Cannon, C.E. Towards Convergence: How to Do Transdisciplinary Environmental Health Disparities Research. Int. J. Environ. Res. Public Health 2020, 17, 2303. [CrossRef]

63. Akompab, D.A.; Bi, P.; Williams, S.; Saniotis, A.; Walker, I.A.; Augoustinos, M. Engaging stakeholders in an adaptation process: Governance and institutional arrangements in heat-health policy development in Adelaide, Australia. Mitig. Adapt. Strat. Global Change 2013, 18, 1001-1018. [CrossRef]

64. Pasquini, L.; Van Aardenne, L.; Godsmark, C.N.; Lee, J.; Jack, C. Emerging climate change-related public health challenges in Africa: A case study of the heat-health vulnerability of informal settlement residents in Dar es Salaam, Tanzania. Sci. Total. Environ. 2020, 747, 141355. [CrossRef] [PubMed]

65. Wang, L.; Liu, F.; Luo, Y.; Zhu, L.; Li, G. Effect of acute heat stress on adrenocorticotropic hormone, cortisol, interleukin-2, interleukin-12 and apoptosis gene expression in rats. Biomed. Rep. 2015, 3, 425-429. [CrossRef] [PubMed]

66. Wyndham, C.H.; Heyns, A.J. The probability of heat stroke developing at different levels of heat stress. Arch. Sci. Physiol. 1973, 27, 545-562.

67. Wyndham, C.H. The effects of heat stress upon human productivity. Arch. Sci. Physiol. 1973, 27, 491-497.

68. Wyndham, C.H.; Heyns, A.J. The accuracy of the prediction of human strain from heat stress indices. Arch. Sci. Physiol. 1973, $27,295-301$.

69. Wyndham, C.H. Research in the Human Sciences in the Gold Mining Industry. Am. Ind. Hyg. Assoc. J. 1974, 35, 113-136. [CrossRef] [PubMed]

70. Ellis, F.P. Heat illness. I. Epidemiology. Trans R Soc. Trop. Med. Hyg. 1976, 70, 402-411. [CrossRef]

71. Kew, M.C. Temperature regulation in heatstroke in man. Isr. J. Med. Sci. 1976, 2, 759-764.

72. Martinson, M. Heat stress in Witwatersrand gold mines. J. Occup. Accid. 1977, 1, 171-193. [CrossRef]

73. Afom, S.B.M.S. Dehydration and serum electrolyte changes in south african gold miners with heat disorders. Am. J. Ind. Med. 1990, 17, 225-239. [CrossRef] [PubMed]

74. Beniston, M. Climatic change: Possible impacts on human health. Swiss Med. Wkly. 2002, 132, 332-337.

75. Donoghue, A.M. Heat illness in the U.S. mining industry. Am. J. Ind. Med. 2004, 45, 351-356. [CrossRef] [PubMed]

76. Ali-Toudert, F.; Djenane, M.; Bensalem, R.; Mayer, H. Outdoor thermal comfort in the old desert city of Beni-Isguen, Algeria. Clim. Res. 2005, 28, 243-256. [CrossRef]

77. Climate change preparations must focus on health disparities. Lancet 2006, 368, 1624. [CrossRef]

78. McMullin, P. Differential diagnosis of sudden high mortality in poultry and game birds. InPractice 2006, 28, 306-311. [CrossRef]

79. Noakes, T.D. Heat stress in sport-Fact and fiction. J. Sci. Med. Sport 2008, 11, 3-5. [CrossRef]

80. Paeth, H. Human Activity and Climate Change in Africa. In Climate Variability and Extremes during the Past 100 Years; Advances in Global Change Research; Brönnimann, S., Luterbacher, J., Ewen, T., Diaz, H., Stolarski, R., Neu, U., Eds.; Springer: Dordrecht, The Netherlands, 2008; p. 33. [CrossRef]

81. Gautret, P.; Soula, G.; Delmont, J.; Parola, P.; Brouqui, P. Common Health Hazards in French Pilgrims During the Hajj of 2007: A Prospective Cohort Study. J. Travel Med. 2009, 16, 377-381. [CrossRef] [PubMed]

82. Paeth, H.; Born, K.; Girmes, R.; Podzun, R.; Jacob, D. Regional Climate Change in Tropical and Northern Africa due to Greenhouse Forcing and Land Use Changes. J. Clim. 2009, 22, 114-132. [CrossRef]

83. Hyatt, O.M.; Lemke, B.; Kjellstrom, T. Regional maps of occupational heat exposure: Past, present, and potential future. Glob. Health Action 2010, 3. [CrossRef] [PubMed] 
84. Tiller, D.K.; Wang, L.M.; Musser, A.; Radik, M.J. Combined effects of noise and temperature on human comfort and per-formance. ASHRAE Trans. 2010, 116, 522-540.

85. Scovronick, N.; Armstrong, B. The impact of housing type on temperature-related mortality in South Africa, 1996-2015. Environ. Res. 2012, 113, 46-51. [CrossRef] [PubMed]

86. Bourdôt, G.W.; Lamoureaux, S.L.; Watt, M.S.; Manning, L.K.; Kriticos, D.J. The potential global distribution of the invasive weed Nassella neesiana under current and future climates. Biol. Invasions 2010, 14, 1545-1556. [CrossRef]

87. Myers, S.S.; Gaffikin, L.; Golden, C.D.; Ostfeld, R.S.; Redford, K.H.; Ricketts, T.H.; Turner, W.R.; Osofsky, S.A. Human health impacts of ecosystem alteration. Proc. Natl. Acad. Sci. USA 2013, 110, 18753-18760. [CrossRef]

88. Liu, K.; Dong, Y.; Huang, Y.; Rasgon, J.L.; Agre, P. Impact of trehalose transporter knockdown on Anopheles gambiae stress adaptation and susceptibility to Plasmodium falciparum infection. Proc. Natl. Acad. Sci. USA 2013, 110, 17504-17509. [CrossRef]

89. Leone, M.; D’Ippoliti, D.; De Sario, M.; Analitis, A.; Menne, B.; Katsouyanni, K.; De' Donato, F.K.; Basagana, X.; Salah, A.B.; Casimiro, E.; et al. A time series study on the effects of heat on mortality and evaluation of heterogeneity into European and Eastern-Southern Mediterranean cities: Results of EU CIRCE project. Environ. Health 2013, 12, 55. [CrossRef]

90. Garland, R.M. National policy response to climate change in South Africa. South. Afr. Med. J. 2014, 104, 584. [CrossRef]

91. Zhao, Y.; Ducharne, A.; Sultan, B.; Braconnot, P.; Vautard, R. Estimating heat stress from climate-based indicators: Present-day biases and future spreads in the CMIP5 global climate model ensemble. Environ. Res. Lett. 2015, 10, 084013. [CrossRef]

92. Gordon, R.E.; Kassier, S.M.; Biggs, C. Hydration status and fluid intake of urban, underprivileged South African male ado-lescent soccer players during training. J. Int. Soc. Sports Nutr. 2015, 12, 21. [CrossRef] [PubMed]

93. Potter, A.W.; Gonzalez, J.A.; Xu, X. Ebola Response: Modeling the Risk of Heat Stress from Personal Protective Clothing. PLoS ONE 2015, 10, e0143461. [CrossRef] [PubMed]

94. Rossi, L.; Interisano, M.; Deksne, G.; Pozio, E. The subnivium, a haven for Trichinella larvae in host carcasses. Int. J. Parasitol. Parasites Wildl. 2019, 8, 229-233. [CrossRef] [PubMed]

95. Bailey, M.S.; Beaton, K.; Bowley, D.; Eardley, W.; Hunt, P.; Johnson, S.; Round, J.; Tarmey, N.T.; Williams, A. Bending the curve: Force health protection during the insertion phase of the Ebola outbreak response. J. R Army Med. Corps. 2016, 162, 191-197. [CrossRef]

96. Coca, A.; Quinn, T.; Kim, J.-H.; Wu, T.; Powell, J.; Roberge, R.; Shaffer, R. Physiological Evaluation of Personal Protective Ensembles Recommended for Use in West Africa. Disaster Med. Public Health Prep. 2017, 11, 580-586. [CrossRef]

97. Stacey, M.J.; Delves, S.K.; Britland, S.E.; Allsopp, A.J.; Brett, S.J.; Fallowfield, J.L.; Woods, D.R. Copeptin reflects physiological strain during thermal stress. Graefe Arch. Clin. Exp. Ophthalmol. 2017, 118, 75-84. [CrossRef] [PubMed]

98. Asefi-Najafabady, S.; Vandecar, K.L.; Seimon, A.; Lawrence, P.; Lawrence, D. Climate change, population, and poverty: Vulnerability and exposure to heat stress in countries bordering the Great Lakes of Africa. Clim. Chang. 2018, 148, 561-573. [CrossRef]

99. Newth, D.; Gunasekera, D. Projected Changes in Wet-Bulb Globe Temperature under Alternative Climate Scenarios. Atmosphere 2018, 9, 187. [CrossRef]

100. Coffel, E.D.; Horton, R.M.; De Sherbinin, A. Temperature and humidity based projections of a rapid rise in global heat stress exposure during the 21st century. Environ. Res. Lett. 2018, 13, 014001. [CrossRef]

101. Ahmadalipour, A.; Moradkhani, H. Escalating heat-stress mortality risk due to global warming in the Middle East and North Africa (MENA). Environ. Int. 2018, 117, 215-225. [CrossRef]

102. Abera, T.A.; Heiskanen, J.; Pellikka, P.; Maeda, E.E. Rainfall-vegetation interaction regulates temperature anomalies during extreme dry events in the Horn of Africa. Glob. Planet. Chang. 2018, 167, 35-45. [CrossRef]

103. Quinn, T.; Kim, J.-H.; Seo, Y.; Coca, A. Comparison of Thermal Manikin Modeling and Human Subjects' Response During Use of Cooling Devices Under Personal Protective Ensembles in the Heat. Prehospital Disaster Med. 2018, 33, 279-287. [CrossRef] [PubMed]

104. Ekiti, M.E.; Zambo, J.-B.; Assah, F.K.; Agbor, V.N.; Kekay, K.; Ashuntantang, G. Chronic kidney disease in sugarcane workers in Cameroon: A cross-sectional study. BMC Nephrol. 2018, 19, 1-8. [CrossRef] [PubMed]

105. Boon, S.D.; Vallenas, C.; Ferri, M.; Norris, S.L. Incorporating health workers' perspectives into a WHO guideline on personal protective equipment developed during an Ebola virus disease outbreak. F1000Research 2018, 7, 45. [CrossRef]

106. Kapwata, T.; Gebreslasie, M.T.; Mathee, A.; Wright, C.Y. Current and Potential Future Seasonal Trends of Indoor Dwelling Temperature and Likely Health Risks in Rural Southern Africa. Int. J. Environ. Res. Public Health 2018, 15, 952. [CrossRef]

107. Sylla, M.B.; Faye, A.; Giorgi, F.; Diedhiou, A.; Kunstmann, H. Projected Heat Stress Under $1.5^{\circ} \mathrm{C}$ and $2{ }^{\circ} \mathrm{C}$ Global Warming Scenarios Creates Unprecedented Discomfort for Humans in West Africa. Earth's Futur. 2018, 6, 1029-1044. [CrossRef]

108. Kadzere, C. Environmentally smart animal agriculture and integrated advisory services ameliorate the negative effects of climate change on production. South. Afr. J. Anim. Sci. 2018, 48, 842. [CrossRef]

109. Wessling, E.G.; Kühl, H.S.; Mundry, R.; Deschner, T.; Pruetz, J.D. The costs of living at the edge: Seasonal stress in wild savanna-dwelling chimpanzees. J. Hum. Evol. 2018, 121, 1-11. [CrossRef]

110. Yezli, S.; Mushi, A.; Yassin, Y.; Maashi, F.; Khan, A. Knowledge, Attitude and Practice of Pilgrims Regarding Heat-Related Illnesses during the 2017 Hajj Mass Gathering. Int. J. Environ. Res. Public Health 2019, 16, 3215. [CrossRef]

111. Moda, H.M.; Filho, W.L.; Minhas, A. Moda Impacts of Climate Change on Outdoor Workers and their Safety: Some Research Priorities. Int. J. Environ. Res. Public Health 2019, 16, 3458. [CrossRef] 
112. Capon, A.; Jay, O.; Ebi, K.; Lo, S. Heat and health: A forthcoming Lancet Series. Lancet 2019, 394, 551-552. [CrossRef]

113. Liu, X.; Tang, Q.; Liu, W.; Yang, W.; Groisman, P.; Leng, G.; Ciais, P.; Zhang, X.; Siao, S. The asymmetric impact of abundant preceding rainfall on heat stress in low latitudes. Environ. Res. Lett. 2019, 14, 044010. [CrossRef]

114. Rasilla, D.; Allende, F.; Martilli, A.; Fernández, F. Heat Waves and Human Well-Being in Madrid (Spain). Atmosphere 2019, 10, 288. [CrossRef]

115. Mastrucci, A.; Byers, E.; Pachauri, S.; Rao, N.D. Improving the SDG energy poverty targets: Residential cooling needs in the Global South. Energy Build. 2019, 186, 405-415. [CrossRef]

116. Jagarnath, M.; Thambiran, T.; Gebreslasie, M. Heat stress risk and vulnerability under climate change in Durban metropolitan, South Africa-identifying urban planning priorities for adaptation. Clim. Chang. 2020, 163, 807-829. [CrossRef]

117. Yengoh, G.T.; Ardö, J. Climate Change and the Future Heat Stress Challenges among Smallholder Farmers in East Africa. Atmosphere 2020, 11, 753. [CrossRef]

118. Cook, T.R.; Martin, R.; Roberts, J.; Häkkinen, H.; Botha, P.; Meyer, C.; Sparks, E.; Underhill, L.G.; Ryan, P.G.; Sherley, R.B. Parenting in a warming world: Thermoregulatory responses to heat stress in an endangered seabird. Conserv. Physiol. 2020, 8, coz109. [CrossRef]

119. Matallah, M.E.; Alkama, D.; Ahriz, A.; Attia, S. Assessment of the Outdoor Thermal Comfort in Oases Settlements. Atmosphere 2020, 11, 185. [CrossRef]

120. Temple, D.; Manteca, X. Animal Welfare in Extensive Production Systems Is Still an Area of Concern. Front. Sustain. Food Syst. 2020, 4, 154. [CrossRef] 